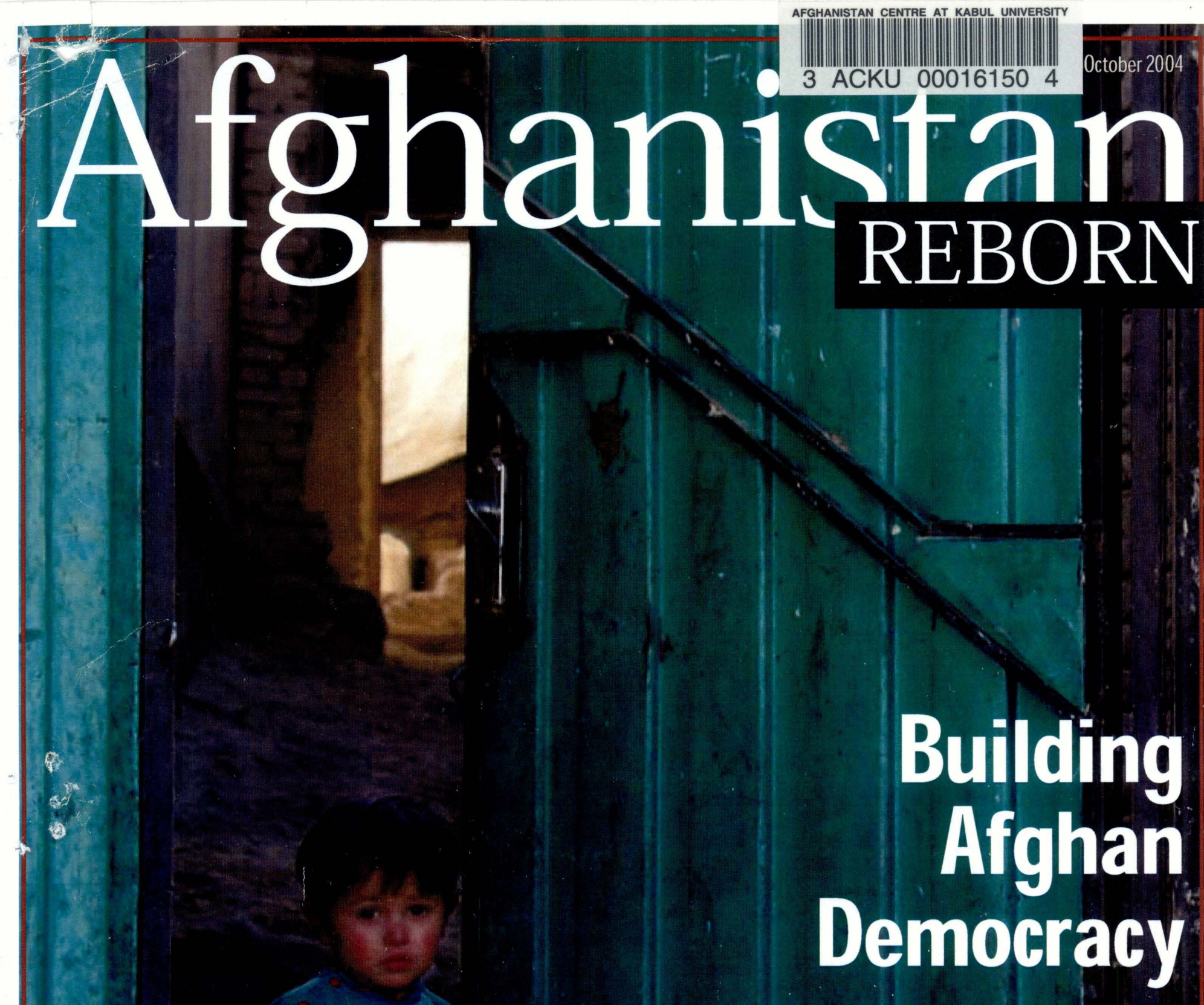

Refugees Return

Schools Rebuilt

Construction Booms 


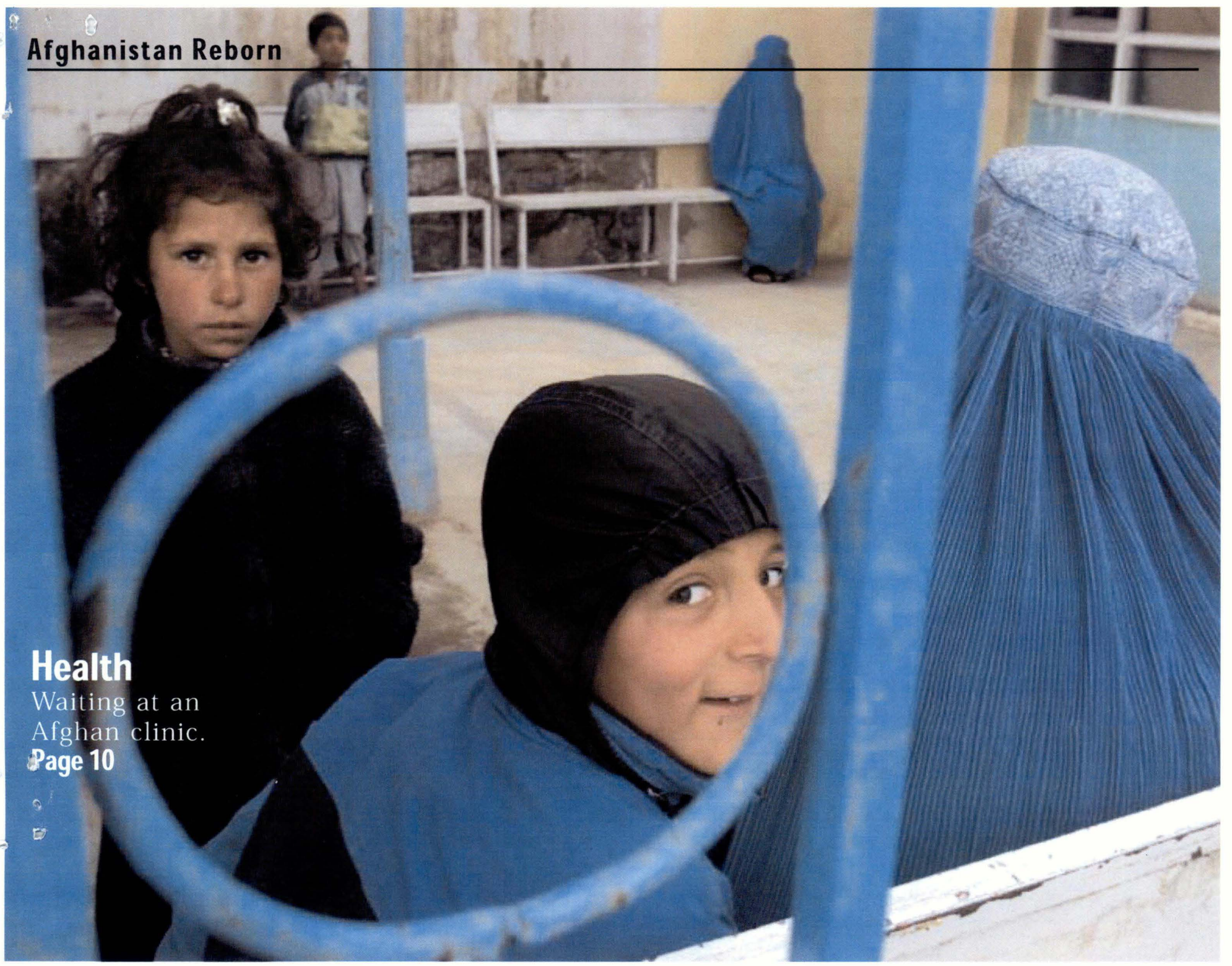

Overview: Afghan and Coalition forces remove Taliban, liberate women, children and minorities and pave way for return of 3.7 million refugees.

\section{Civil Society}

Building Democracy: A Loya Jirga council appoints a new interim Afghan government which registers 10 million voters for first elections.

\section{Essential Services}

Thirst for Education: School enrollment leaps from 900,000 to 5 million as girls and returning refugees fill classrooms.

\section{Health of a Nation: Vaccinating}

millions and improving maternity care lowers mortality levels for women and children.

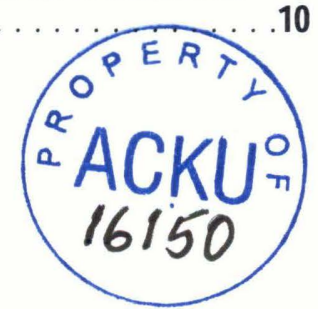

Reconstruction: Roads, ministries, hospitals, schools, hotels, sewage and water systems are repaired or built from 2 scratch.

\section{Economy}

\section{Industry and} Agriculture: New (n) stability and road work spark growth of business, construction and farming.

\section{Building Peace:}

6 As militias disarm,

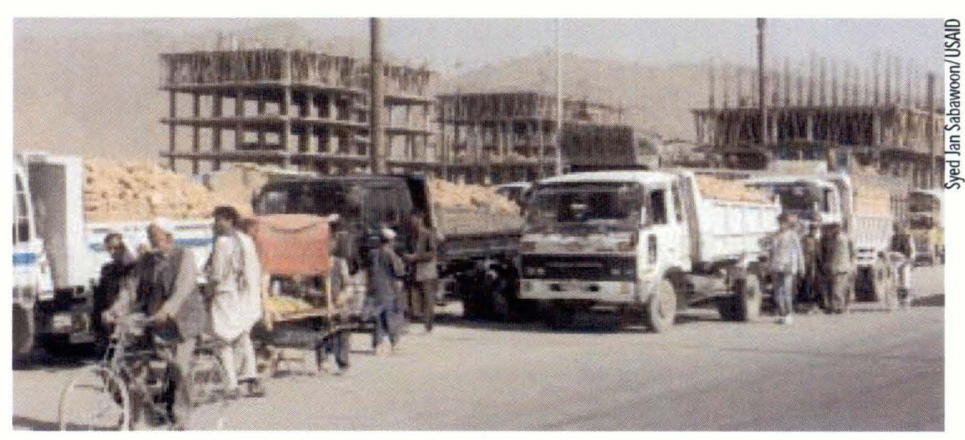

An Ancient History: Afghanistan has long been a place where cultures meet and empires rise and fall from Alexander to the new Afghan National Army and police force take to the field.

\section{.18}

International Cooperation: Aid

10 international organizations work together to restore Afghanistan. . . . . . . . . . 20
Map of Afghanistan Projects .24

Top Ten: The ten most important achievements of U.S. and international assistance in Afghanistan. .... . Back Cover 
Largest refugee return in modern world history shows confidence and hope

\section{Kabul, Afghanistan}

$\mathbf{Y}$ ou can witness the rebirth of Afghanistan after 23 years of savage warfare by going to the United Nations Refugee Center here. Painted trucks laden with refugees return each day from Pakistan and Iran bearing hundreds of Afghans to their homeland. Month by month they flow back home.

Already 3.7 million Afghans have returned from refugee camps since the Taliban's repressive rule ended in November 2001. It is an epic pilgrimage of an entire people, from wizened old men and women to small children born far from their homeland. They are carrying the poles of their refugee shacks, their goats, their woven clothes and pots and pans, returning to their -illages and farms to begin life anew.

They are voting with their feet by rejoining a country that defeated communist troops from the Soviet Union but then fell prey to fanatic religious Taliban zealots aligned with terrorist Osama bin Laden. At a U.N. compound, the refugees get $\$ 13$ per person, vaccinations, a lesson on the dangers of land mines, and transport back to their towns and villages. They also get food for six months and other help to restart their lives.

Since U.S. troops helped the Afghans get rid of the Taliban in November 2001, the refugees have had but one thought-it's time to go back home.

"I earned more money each day in Pakistan," said one young man as he filled a water jug on a hillside neighborhood of Kabul. "But this is our home."

In Mazar-i Sharif, the principal of Nau Behar School said that his enrollment has in-

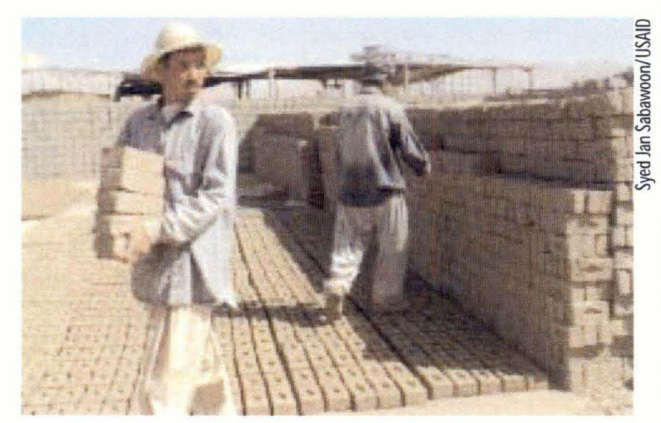

Afghan workmen make bricks at a Kabul building project rising amid the rubble left by war. creased from 400 students to 2,500 since the Taliban were defeated, allowing girls and refugees to return to class. Children wait outside the school for one of the three shifts to begin, crowd the newly painted hallways or sit at new desks in tents erected in the courtyard.

Another sign of the new life in this ancient land, which ruled much of India in the 1500s under the Moghul Emperor Babur, can be seen along the highway leading into Kabul from the northern Shomali plains. Truck after truck rolls by laden with building stone, bricks, and gravel. A construction boom has seized Afghanistan. Homes, mosques, hotels: Everywhere people are making bricks and cement blocks. Steel reinforcing bars poke crooked fingers into the sky from a hundred cement footings rising amidst the ruins of Southwestern Kabul along Darulaman Avenue.

Once, this area was the front line between rival mujahidin fighters seeking to control the power vacuum left when the Russians had had enough and went home in 1989. The factional fighting ended when the

\section{In 2004, some 500,000 had} returned by August. In July alone, 120,000 people came home-without fanfare or press coverage, joining the biggest voluntary repatriation of refugees in modern world history.

ultra-religious Taliban formed an army in the refugee camps and seized power in 1996. The Taliban barred women from work and schools, outlawed television and music, forced people to pray, destroyed 2,000 year old giant stone Buddhas at Bamiyan, and invited Osama bin Laden to operate Al Qaeda's terrorist training camps.

The September 11 attacks led the United States to overthrow the Taliban, routing $\mathrm{Al}$ Qaeda and sparking the rebirth of the country amid the ruins of the fighting.

Today, workers put the finishing touches to a brand new dormitory for 1,100 girls at Kabul University, built by the United States Agency for International Development (USAID). At a clinic in Charikar north of Kabul,
Northern Alliance commander Ahmad Shah Masood killed

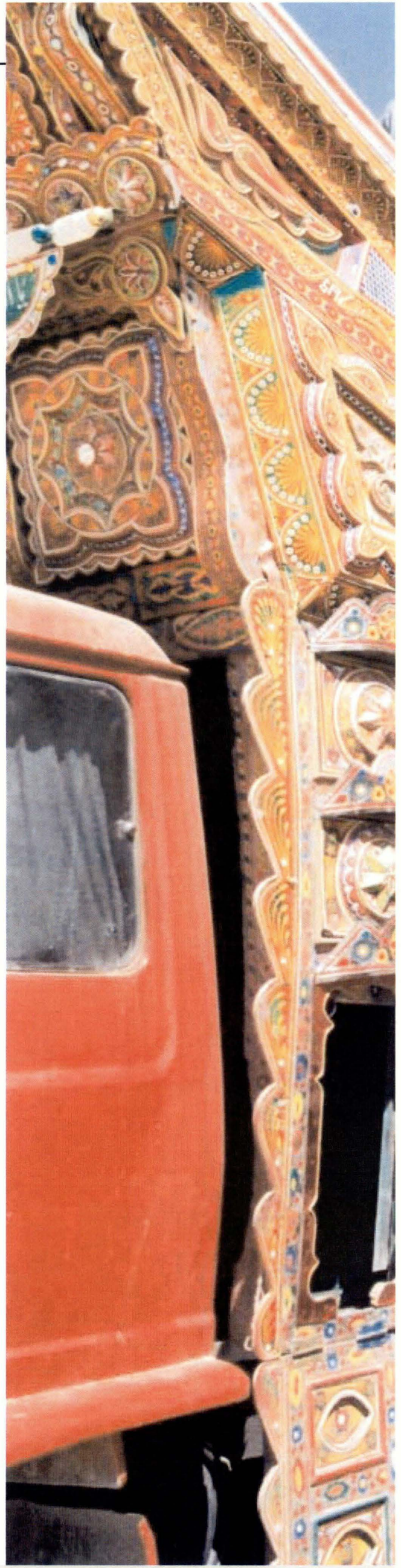

US, British forces strike Taliban, al Qaeda
President Bush announces $\$ 320$ million Afghan aid package 


\section{Building Democracy}

\author{
Ten million Afghans- \\ $41 \%$ of them women- \\ register to vote
}

\section{Ghazni, Afghanistan}

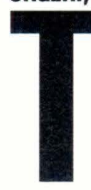
he pink and blue election poster shows women casting their ballots. Some wear headscarves, some have the full burka covering their faces. One woman has a crutch, reminding us of the many Afghan land mine victims. The poster is plastered on the ancient-looking mud wall of a building in Tormay Village, perched on a hillside overlooking lush fields of tomatoes, potatoes, apples, corn, and other crops.

The village way of life seems reassuringly traditional and ancient, with boys and girls leading their sheep and cows along worn dirt paths between the fields. But the poster gives one an inkling of the huge changes coming to this ancient land.

Already Afghans have sent representatives to two Loya Jirgas-councils that decided on the interim government and then adopted a constitution and set elections for president on October 9 this year and for parliament in 2005.

In Tormay, Jalalabad and across this Texas-sized country, candidates have formed 20 political parties and are joining coalitions and preparing posters and radio advertisements. For people who lived under a monarchy and then communism and finally a medieval theocracy that stoned people to death for religious crimes, this is a new era.
"A lot of people argued the people were not ready for elections-they were proved wrong so far," said U.S. Ambassador to Afghanistan Zalmay Khalilzad.

Although the Taliban threatened to kill anyone who registers to vote, with the help of USAID, the United Nations, and other aid groups, over 10.5 million Afghans registered to vote-more than the original estimate of 9.8 million eligible voters.

What's more, in a land where only three years earlier the Taliban barred women from even leaving their houses unless accompanied by a male relative, 41 percent of those who registered were women.

"The participation is amazing," said David Singh, spokesman for the UN Assistance Mission in Afghanistan. "There was a lot of skepticism about this process at the beginning, but the targets have been fulfilled."

Jawad Ludin, the spokesman for President Hamid Karzai, was equally elated.

"We are overwhelmed with joy at the sheer enthusiasm of the people," Ludin said.

A poll by the Asia Foundation released July 13 reported that 64 percent of Afghans think their country is heading in the right direction, with only 11 percent saying it's going in the wrong direction. Some 81 percent said they plan to vote and 77 percent said they thought the elections would "make a difference." The survey, carried out under a USAID grant, was conducted in 29 of 32 provinces containing 94 percent of the Afghan people. It showed 91 percent of Afghans were aware of the elections and wished to participate.

\section{"We have never had elections but we know that other people have them and we want to decide who will rule us." \\ Afghan farmer outside Jalalabad}

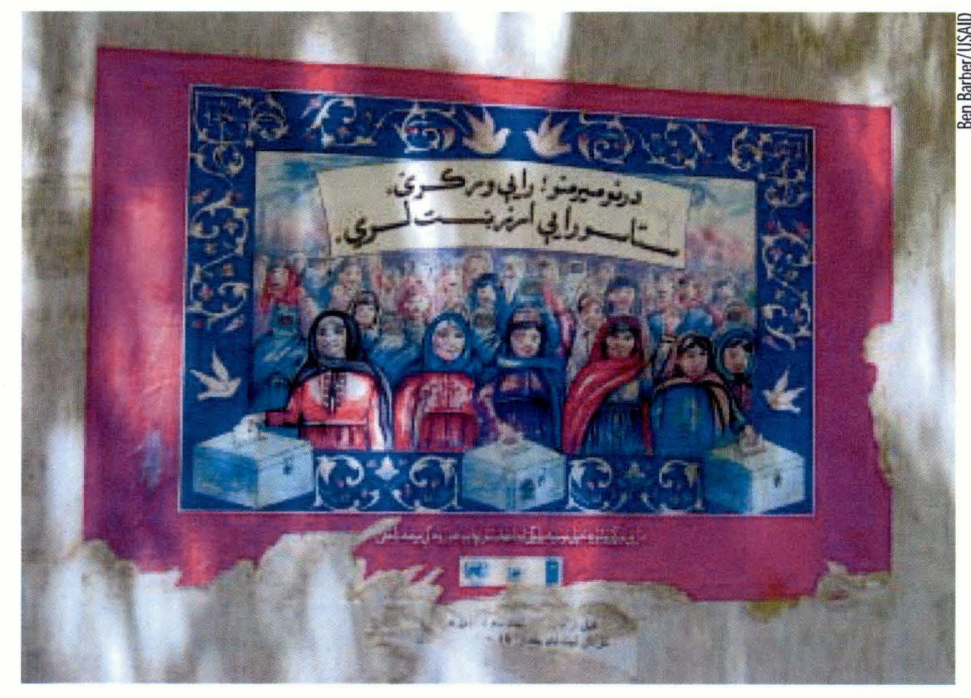

Election poster plastered on Kabul building shows women with headscarves and veiled burkas voting for the first time. Pashtu inscription says "Dear women,

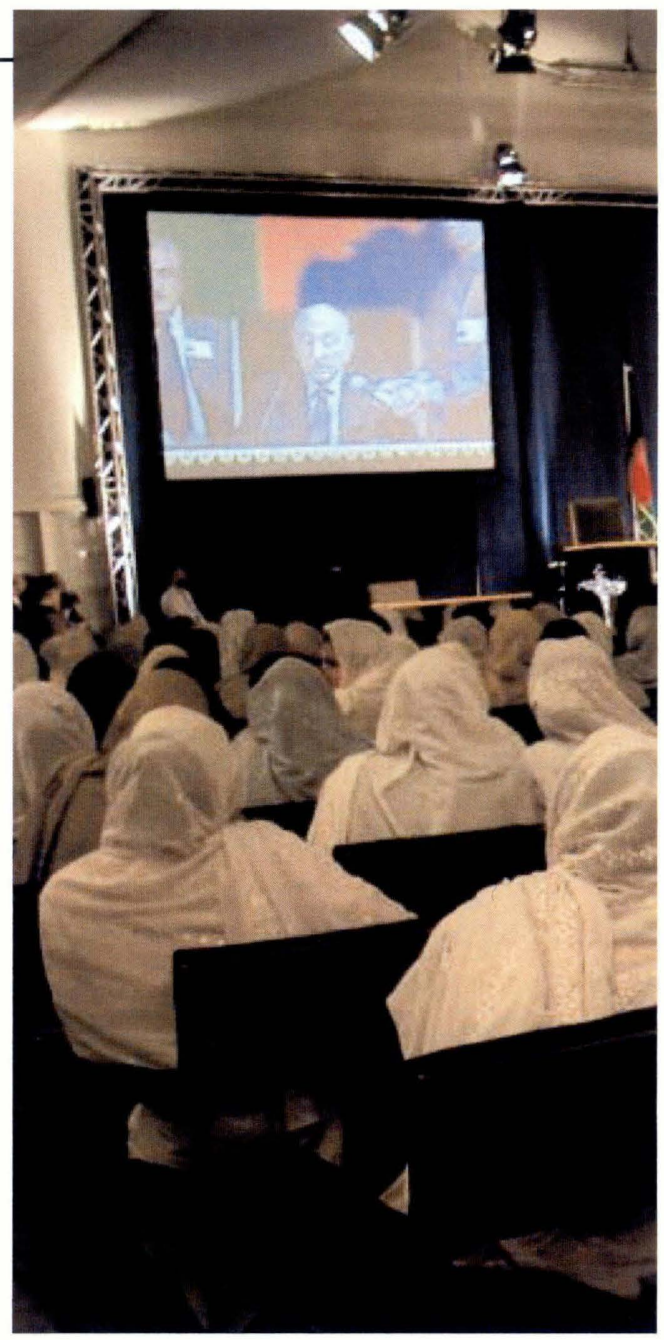

Women delegates at a Loya Jirga listen to King Zahir Shah.

The voter registration cards proved of value to the Afghans as their first and only identity card. Although some Afghans had registered more than once, voters will have to dip a finger in indelible ink that will take days to wear off, preventing them from voting a second time.

"The goal of the coalition is a country that stands on its own feet... that no longer hosts international terrorists focused on the destruction of the world as we know it," said Khalilzad at a conference at Bagram air base near Kabul.

"We want to get Afghans working for themselves by standing up a government working for the wishes of its people. We're not seeking to have them copy the U.S. system, but people here want a voice in the selection of their government."

In June 2002, an Emergency Loya Jirga established the Transitional Islamic State of Afghanistan. A second Loya Jirga adopted a new constitution establishing an Islamic Republic in January, 2004. Former King Zahir Shah holds the honorific title, "Father of the Country," but lacks any governing authority. The government will consist of an elected president, two vice presidents, and a nation-
Tokyo Donors Conference

$\$ 2$ billion pledged for reconstruction
Child vaccination program begins

Karzai signs Declaration of Essential Rights of Afghan Women

ISAF force arrives
Security Council ad opts sanctions against al Qaeda, Taliban

U.S. pledges ad ditional $\$ 296$ million to Afghan reconstruction
Peshawar Voluntary Repatriation Center opens

First units of new Afgha

Army start training 


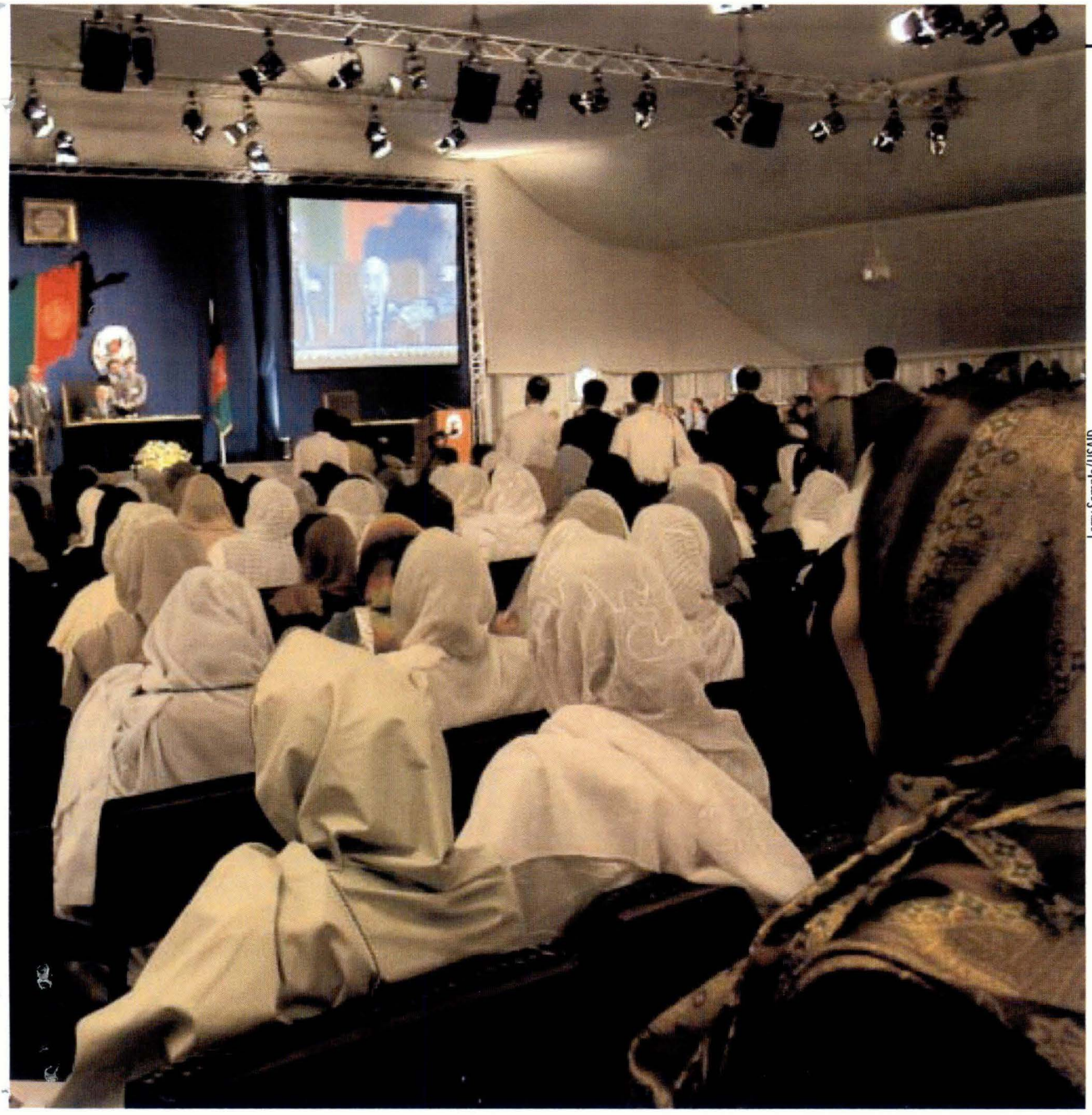

al assembly consisting of two houses: the House of People (Wolesi Jirga), and the House of Elders (Meshrano Jirga). There will also be an independent judiciary.

\section{Extending the Government's Reach}

With the routing of the Taliban, a key remaining challenge was the need to extend the reach of the national government to the provincial and district levels, particularly in areas controlled by strong regional leaders who defeated the Soviets and the Taliban.

The interim government led by Hamid Karzai-with U.S. and international support-has urged these regional leaders to demobilize their private militias and turn in their weapons, to allow their forces to be replaced by the Afghan National Army (see page 18), and to wind down their roles as military commanders and to become civil or political leaders instead.

As Ambassador Khalilzad has said, "We are breaking the back of the problem of warlordism." Regional leaders increasingly are accepting the extension of the authority of the national government, as Karzai has appointed new provincial governors, police chiefs, and corps and division commanders.

More and more, differences among key leaders and factions are being channeled into political processes, rather than military competitions or clashes. Even those who support regional leaders are calling on Afghans to work out the appropriate distribution of power and responsibilities in the national government through the future parliament and constitutional means.

\section{Radio Key to Political Awakening}

Since 85 percent of Afghans cannot read and many live in remote regions without the opportunity or the cash to buy newspapers and magazines, radio has become the key to informing citizens about building democracy. Dozens of new radio stations have taken to the airwaves, supported by grants and training programs from USAID, the European Union, United Nations, and many nongovernmental organizations (NGOs).

AIINA is one of these NGOs. Backed by U.S., French, Finnish, Japanese, and other aid programs, it produces newspapers, magazines and radio news programs which it distributes around the country.

AIINA, in collaboration with UNESCO and the Women Publishing Group, started the first community radio programming for Afghan Women in March 2003, and in a few months was broadcasting four hours per day in both Dari and Pashto, the major languages of the country.

Azizullah, 30, is the editor of another

\section{Results}

- In June, 2002, a Loya Jirga created a Transitional Islamic State headed by interim President Hamid Karzai.

- The first presidential elections in Afghan history set for this 0 ctober, parliamentary elections follow in 2005.

- Twenty parties register and 18 candidates enter presidential race.

- 10 million Afghans register to vote despite

attempts by Taliban and other groups to disrupt the process.

- $41 \%$ of those registered are women; under the Taliban few were allowed to work or leave home let alone vote.

- In January 2004, another Loya Jirga adopts a constitution creating an Islamic republic.

Newspapers and radio reopen; debate and free media emerge.

AÏNA product: a glossy bimonthly children's magazine called Parwaz which means "flying." It reaches 500,000 children. Articles aim to subtly teach Afghan children to respect those who are different from them-not to hate them as the Taliban did. "One article tells how bubble gum is used by children around the world," Azizullah said. "Indirectly, Afghan kids learn that there are kids in America and elsewhere who like gum."

The Islamic clergy nearly banned the magazine for an article about a Muslim, a Christian, and a Jewish child who are all friends. However, Azizullah said when he explained the intent of the story, the clerics dropped their opposition.

"My idea is that the magazine goes through the children to the family," Azizullah said. "In most of Afghanistan, the children can read, not the parents."

In another Kabul house, the first Afghan news service-Pashwak-was training reporters and preparing to distribute its reports to radio stations, newspapers and other customers. The reports are being copied onto CDs and an NGO delivers them around the country to 50 radio stations. The Institute for War and Peace Reporting, an international NGO, trained the Pashwak staff, headed by news editor Abdul Rauf Liwal.

"This is important because we are part of the first democratic election in the entire Afghan history," said Liwal as reporters stood in line to have him edit their copy. "After 23 years we are going towards peace.

"We also have the role of bringing what the people want to the government and what the government is doing to the people. The people endured such horrendous times in the Taliban era. They are thirsty for this openness. It's like taking birds out of a cage.

"This is the first time in this country's history we can write and say what we want."

King Zahir Shah re turns to Afghanistan
Pakistan's President Musharraf visits, pledges cooperation 


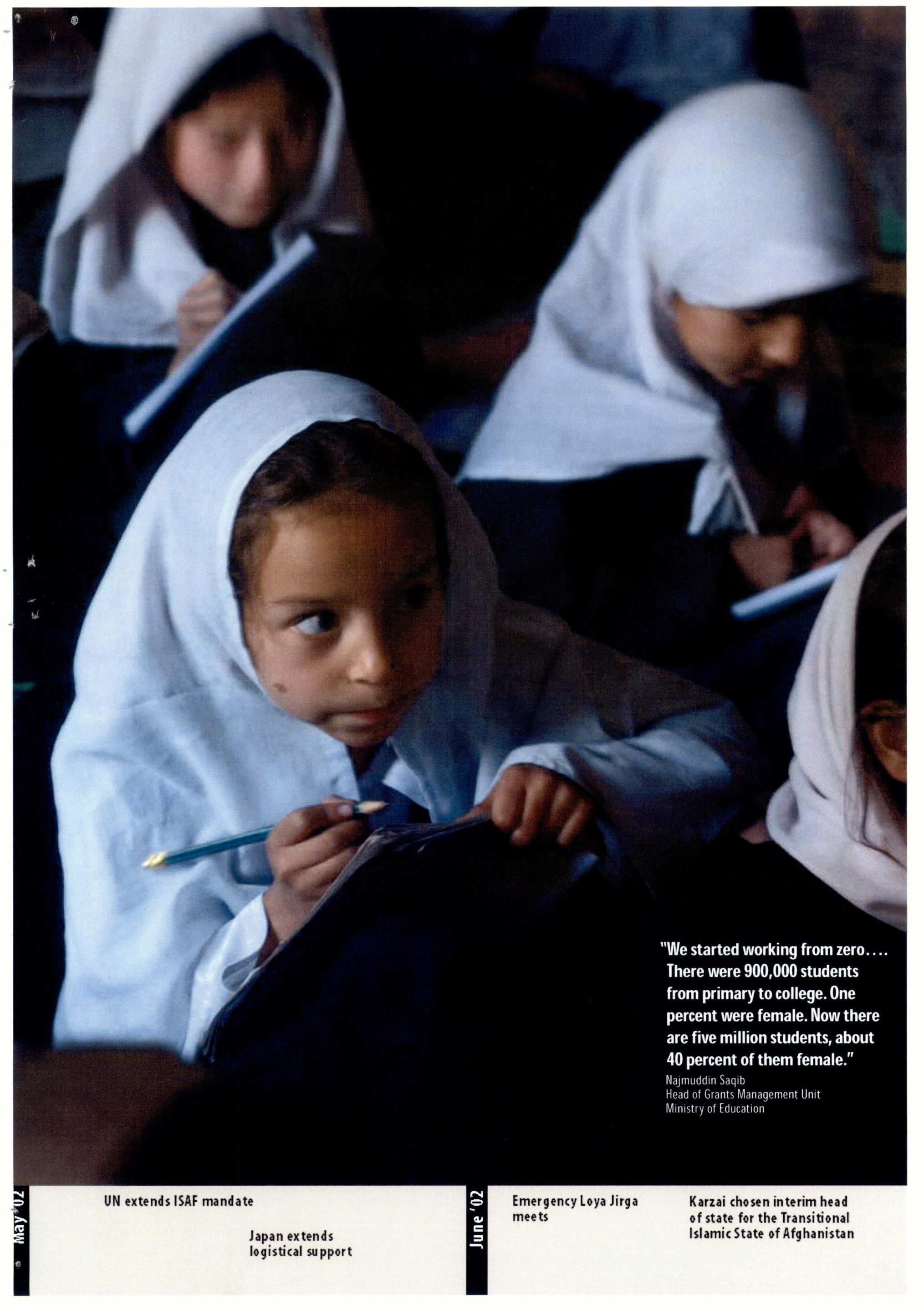




\section{A Thirst for Education}

\author{
Thirst for education \\ has quadrupled school \\ enrollments
}

n Mazar-i Sharif, the Nau Behar School used to have 400 students when the Taliban ruled Afghanistan, just three years ago. This August, 2,500 students enrolled according to headmaster Ghulam Yashiya. Hundreds of children-boys along with girls-packed the street in front of the school waiting for their shift to begin. Three shifts plus several tents in the playground are needed to cope with the new thirst for education. Although the school was newly painted and rehabilitated under a USAID grant, it will require enlargement to accommodate the new students, many back from refugee camps in Pakistan and Iran. Other parents simply realized, with the Taliban gone, that reading, writing and math will help their children a lot more than the fundamentalist religious studies the Taliban favored-and allowed only to boys.

In another part of Mazar-i Sharif, which sits astride the Silk Road linking China with Europe in ancient times, Anif Azhari, 15, sits in his classroom at the Lycee Bakhter and opens up a book printed by USAID and distributed by the UN throughout the country. "We all want to go to the university and become doctors or engineers and serve our country," said Azhari, as his classmates nod in agreement. Here, too, outdoor tents add space for the overflow students.

Aid groups are pouring more than $\$ 100$ million into new textbooks, rehabilitating or building new schools, helping more than 170,000 students catch up from the lost years when the Taliban ruled, and training more than 20,000 teachers by radio programs and seminars. U.S. funds earlier helped publish millions of Afghan school books which were distributed by the United Nations in time for the first school year after the Taliban were routed.

At Kabul University, the United States gave $\$ 9$ million to build a giant dormitory for 1,100 women students. It rises just a few dozen yards from the crumbling ruins left behind by years of warfare.

In Balkh University in Mazar-i sharif, the major learning institution in northern Afghanistan, the United States has offered to build a new faculty of agriculture.

"I want to study engineering so I can build apartments and schools and help people," said Zahiruddin, 17, sitting with friends in the university library. "The teachers are good but we have 300 students in a class. We need a lot more books for the library."

While no women were allowed to study until the Taliban were ousted in 2001, now 40 percent of students are women such as engineering student Shekiba Khoram, 22.

"Some people don't want women to have the same rights as men," she said. "Rights are not given. We should get it. We should try to get our freedom, our rights.

"We face lots of problems. In some places we are not allowed to go alone. In some places there are forced marriages. I don't have problems, but other girls do." She is working with a group arranging meetings to protect against forced marriages.

"We don't need money-we just need spiritual support," she said.

According to the head of grants at the Ministry of Education, Najmuddin Saqib, 42, the main aid donors to education include the World Bank, the United States, Japan, the Asian Development Bank, France, and Denmark.

"We started working from zero-there was no system you could call education," said Saqib in an interview in his office. "Our schools were converted to madrassas or military training for Taliban. There were 900,000 students from primary to college. One percent were female. Now there are five million students, about 40 percent of them female."

In many districts, officials say that although they have 200 or 300 schools, only 10 or 15 percent have buildings. The rest meet under a tree or crude shelter.

Saqib said: "We started developing a new curriculum framework. Now we start writing textbooks. We hope to print new ones with four colors like every European country. We're doing grades one and four. Later we'll do the others." Columbia University in New York is working with UNESCO, UNICEF, and the World Bank on the textbook project.

Afghanistan has 102,000 teachers but needs 30,000 more, especially in rural areas, he said. Columbia University is helping out by training the teachers as well as school principals and education planners in the ministry.

"Foreign assistance is extremely essential," said Saqib. "In two years we built 1,800 new schools. We trained 50,000 teachers last year. We plan to train 105,000 teachers in the next six months. For this we need $\$ 27$ million and we already have $\$ 12$ million available."

\begin{tabular}{|c|c|}
\hline \multicolumn{2}{|l|}{ Results } \\
\hline $\begin{array}{l}\text { Millions of girls } \\
\text { barred from school by } \\
\text { the Taliban since } 1995 \\
\text { have returned to their } \\
\text { classes. Today, } 40 \text { per- } \\
\text { cent of all students are } \\
\text { female. } \\
\text { - Enrollment in all } \\
\text { schools, from primary to } \\
\text { college, jumped from } \\
900,000 \text { in } 2001 \text { to } 5 \\
\text { million. Many are } \\
\text { among the } 3.7 \text { million } \\
\text { refugees who returned } \\
\text { to Afghanistan from } \\
\text { Pakistan and Iran. }\end{array}$ & $\begin{array}{l}15 \text { million textbooks } \\
\text { were printed and dis- } \\
\text { tributed for the fall, } \\
2002 \text { school year. } \\
1,800 \text { schools were } \\
\text { built by Afghan and for- } \\
\text { eign aid agencies. } \\
50,000 \text { teachers were } \\
\text { trained. } \\
\text { A dormitory for } 1,100 \\
\text { women has been built } \\
\text { at Kabul University. }\end{array}$ \\
\hline
\end{tabular}

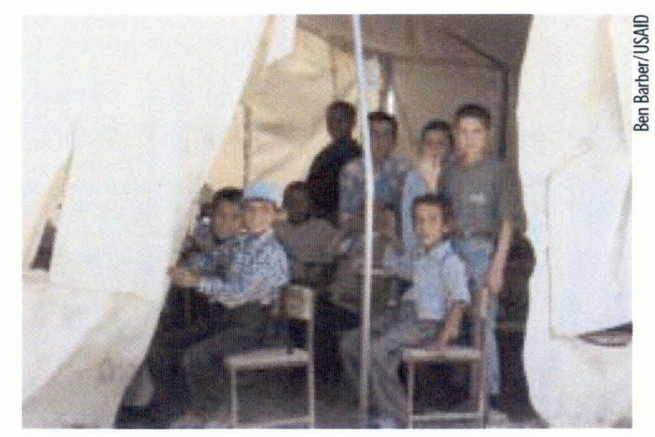

Boys attend class in a tent at Nau Behar School in Mazar-i Sharif. Enrollment leaped from 400 students in 2001 to 2,500 students in

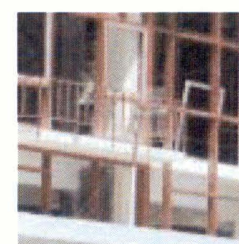

2004 after girls were allowed to return to classes and refugees returned from abroad.

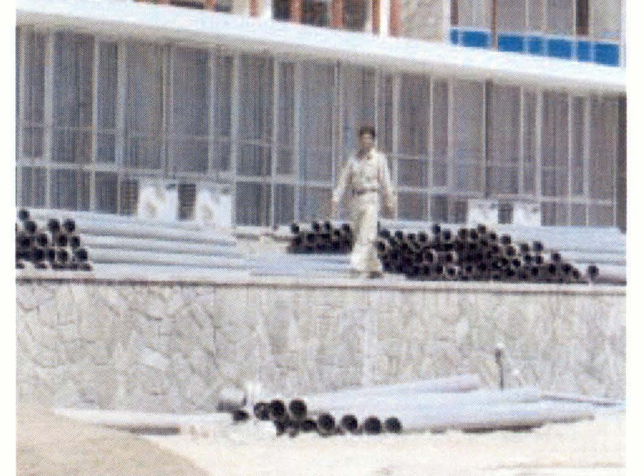

Workman finishing up the large new dormitory for women at Kabul University built by USAID. The univer- sity stands in a heavily damaged part of the city that was a frontline for factional fighting in the 1990 s. 
Students at the Bakhter High School in Mazar-i Sharif sit wait-

ing for their teacher to enter the classroom. The 8,000 students in the prestigious school, where many Afghan leaders

have studied, attend in three

shifts and use tents in the courtyard to deal with crowding.

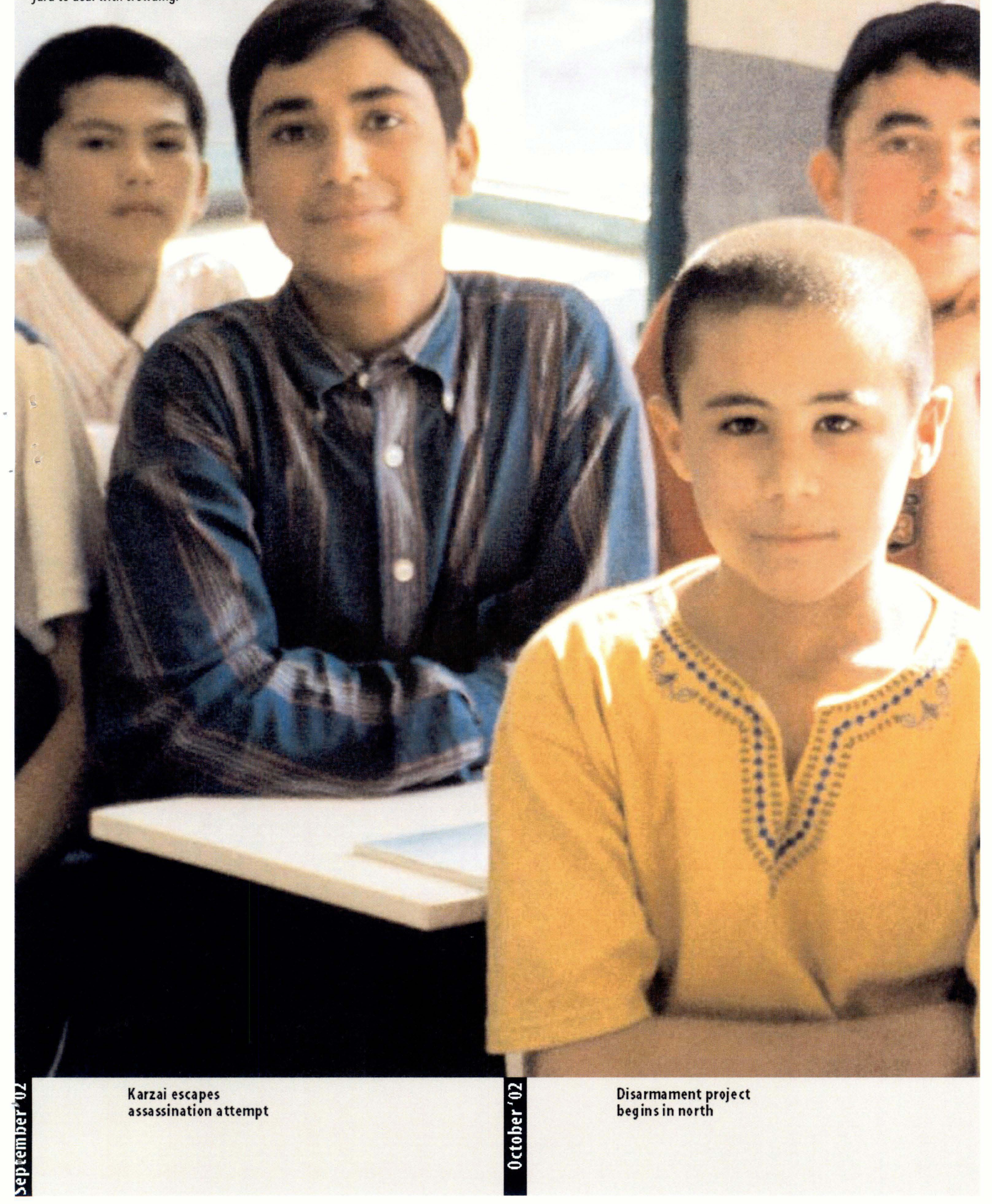





\section{The neglected Afghan} health care system is rebuilt from the ground up.

\section{W}

W omen wearing blue burkas crowd the health education room at the new clinic, their children staying close and respectful as they wait for the nurse to begin the lesson. The kids may sense that the vaccine injections will follow.

Nafasgul, 32, (who uses only one name) walked the two miles from her home with her son Firdaus, 2. He has a stomach ache, nausea, and diarrhea and he can't sleeptypical symptoms of the worms or intestinal diseases that affect millions in Asia.

"During the Taliban time, we couldn't even leave the house to do minor things for ourselves. Now we leave the house to do our things, to take the children to a doctor, to go to the market, to visit relatives, or take the kids to a park in the evenings and simply walk around," she said through an interpreter.

"Before, I could not even take my child to a doctor."

The clinic is the first of 226 being built by USAID, one of several national and international aid groups renovating and building clinics and hospitals, training Afghan nurses and doctors, and providing clean, potable water systems. Aid groups also work with the Ministry of Health to train senior staff and district health officers.

"Now the donors give money directly to NGOs such as MSH [Management Sciences for Health] and CHF [another NGO], which operate primary health care," said Peter Saleh, a Farsi-speaking U.S. health care advisor to the Afghan government. "The goal is to prepare the Ministry of Health to take over delivery of health care."

Afghanistan is healthier today than it was when the Taliban barred women nurses and doctors, prevented women from leaving their homes to seek medical treatment for themselves or their children, and turned back the calendar on medical services 100 years.

Some vital statistics: life expectancy is 46 ; the population is growing at close to five percent a year; the birth rate is one of the highest in the world at seven to 10 per woman; 165 of every 1,000 children die in their first year and two of every 100 women die in childbirth. U.S. aid programs have rehabilitated 72 health clinics, birth centers, and hospitals; provided funding to UNICEF to treat 700,000 cases of malaria; vaccinated 4.26 million children against measles and polio, likely preventing some 20,000 deaths; and provided basic health services to more than 2 million people in 21 provinces. The U.S. civilian and military aid programs also are upgrading the Rabia Balkhi and Malalai hospitals for women in Kabul, while U.S.

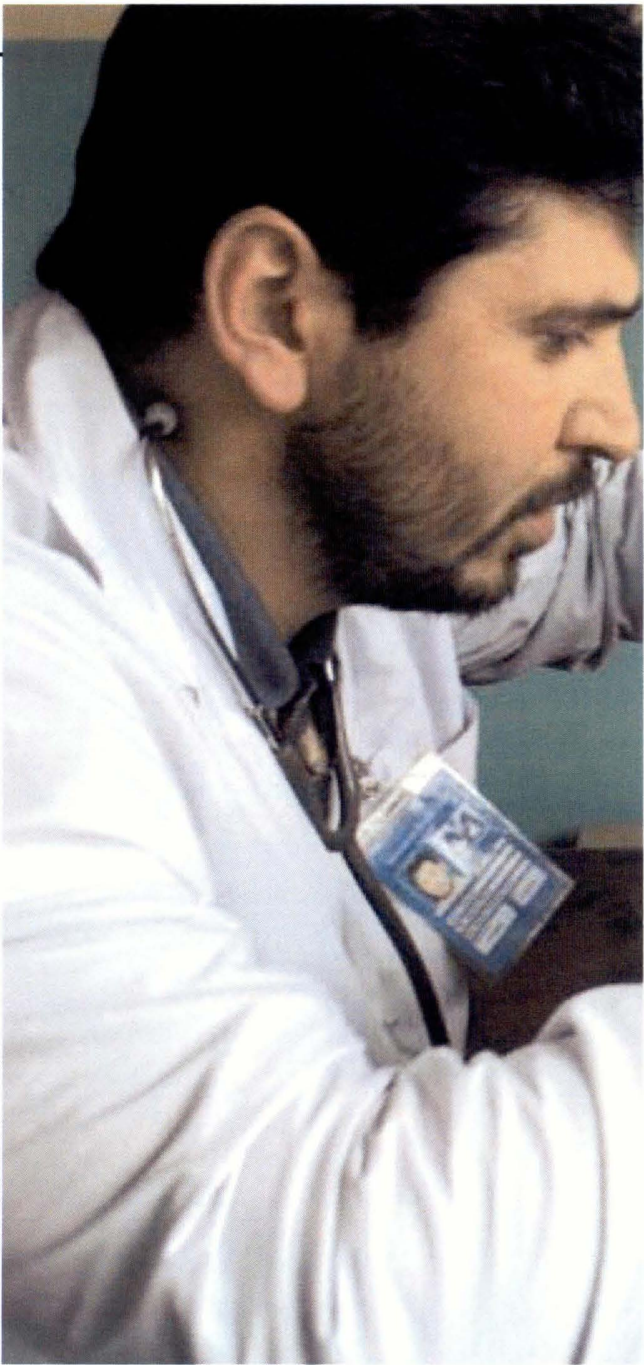

A male doctor is now allowed to treat a child held by its mother since there are no longer any Taliban the home and having any contact with men outside their family. limits on women leaving

\section{Provincial Reconstruction Teams}

US reconstruction aid is being delivered through a new concept created for the Afghan crisis: the Provincial Reconstruction Team. PRTs operate from fortified bases. From there soldiers and civilians can deliver aid in relative safety.

Some 19 PRTs have been set up. Britain, New Zealand, Netherlands, and Germany run six; U.S. forces run the rest. Protected by 80 to 90 troops, PRTs work closely with village leaders on projects like schools, clinics, and water systems.

Many NGOs pride themselves on being neutral in conflicts, serving humanitarian goals without taking sides. However the armed attacks on aid workers in Afghanistan by Taliban, Al Qaeda and other forces-who oppose all Western-supported projects - has made it essential that USAID and many other aid groups work closely with military units. It's an important innovation that has delivered a lot of aid over the past year.

Currency conversion completed

\section{U.S. Military Doctors Treat 800 Patients in a Day}

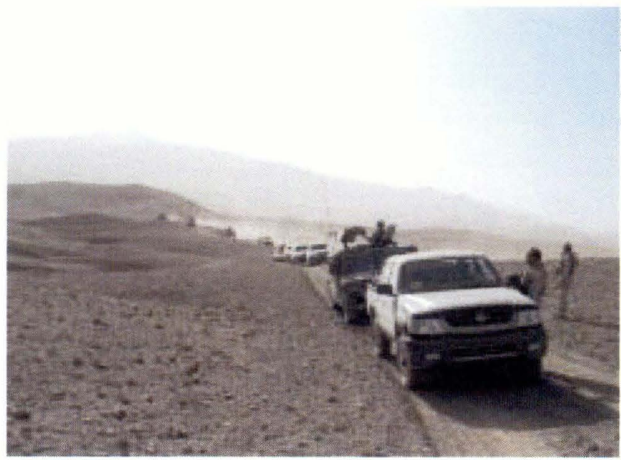

On an early August morning, a military medical team set out from a fortified PRT compound, rolled through Ghazni, the main city between Kandahar and Kabul, to a lush valley packed with orchards, fields and small villages.
At the village of Tormay, Dr. Steve Jones, 51, a U.S. National Guard colonel from Ft. Campbell, Kentucky, and the leader of the medical team, found an unused girls' high school - the fall classes had not yet begun-with two entrances so that women and men could be treated separately.

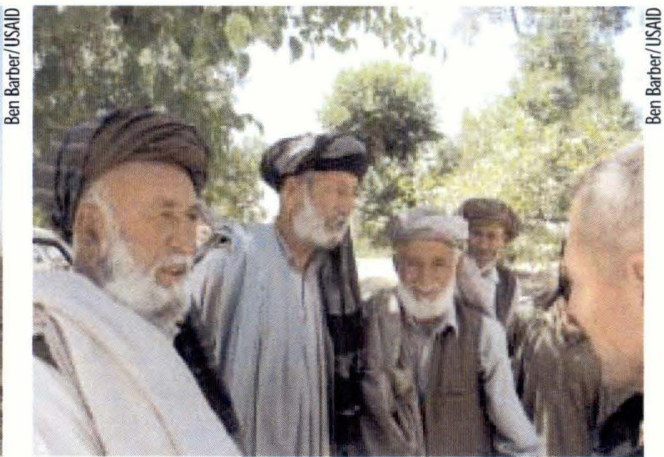

Dr. Jones asked the janitor to get the town elders, four white-bearded men, who agreed to let the team use the school to treat people and their farm animals. "You came to help," said one eld er. "Our duty is to get the people to come here. 


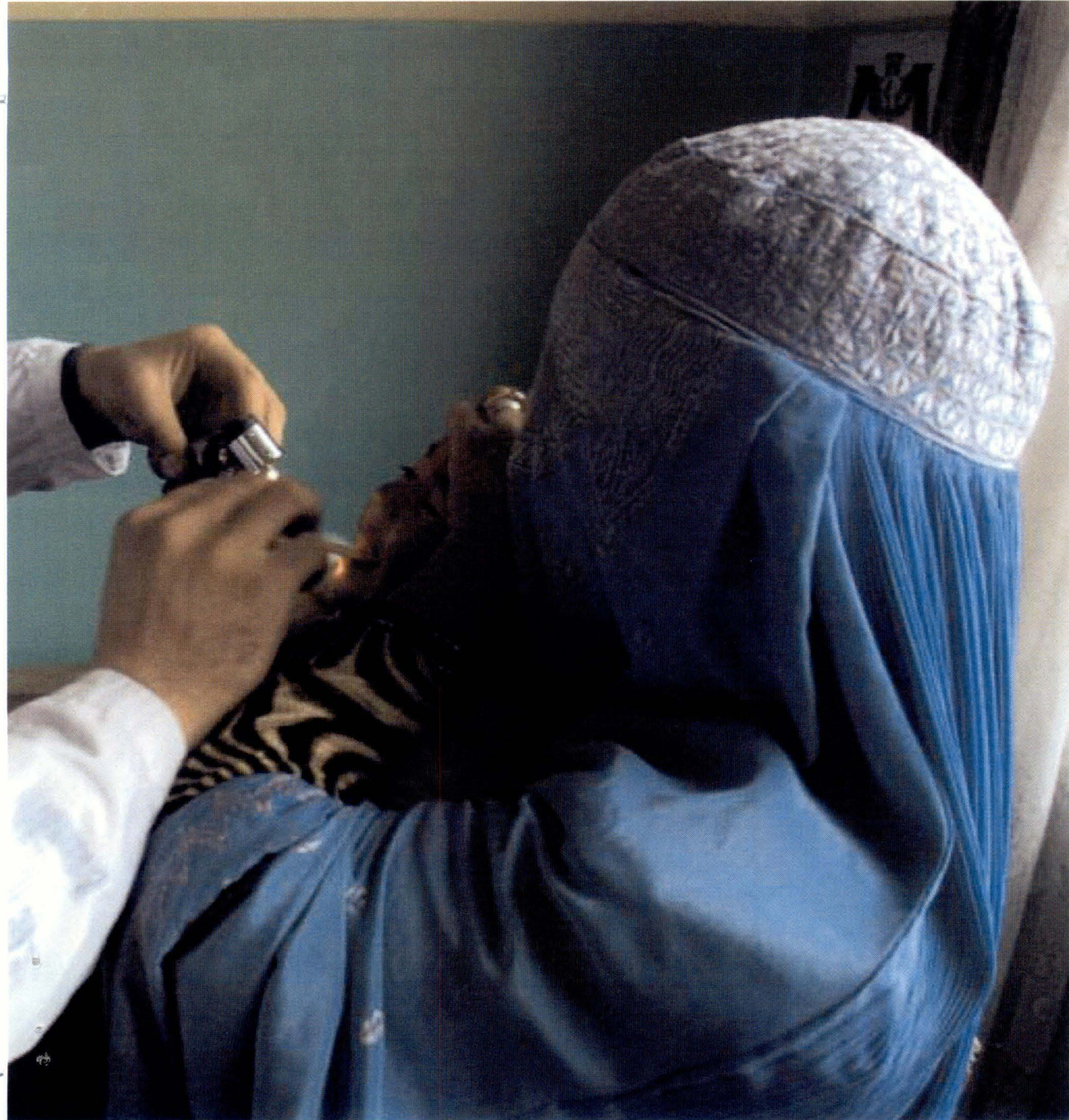

"During the Taliban time, we couldn't even leave the house... to take the

children to a doctor," Nafasgul, 32, said as she waited with her children at a new clinic.

\section{Results}

- Clinics, birth centers, and rebuild 550 rural and hospitals have been health centers. rehabilitated across Afghanistan.

- Funded via UNICEF treatment of 700,000 cases of malaria.

- Upgrading the technical skills of the Ministry of Health. Currently, most health care is still managed by NGOs.

- Vaccinated 4.26 million children against

- Providing basic health services to more than 2 million people in measles polio, preve ing some 20,000 deaths.

- Surveyed health facilities and services throughout country, helping Ministry of Health expand basic services for $\mathbf{1 6 . 5}$ million women and children women and children.

- CARE, with funding from US and others. supplies $1 / 4$ of Kabul's water. Rehabilitating water systems in Kandahar and Kunduz.

army doctors are treating thousands all over Afghanistan.

The lack of clean water for drinking and washing causes chronic stomach illnesses, draining the health and energy of many people. Aid groups have sponsored the use of chlorine to purify water. The U.S. also works with CARE to supply 600,000 people in Kabul clean drinking water and to dig wells throughout the country. Foreign aid also hires teams to clean out drainage ditches so that waste water flows away from populated areas.

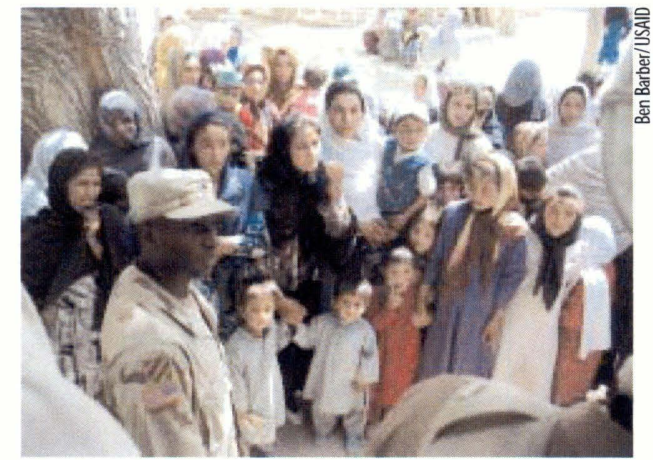

They sent out men on motorcycle and on foot to alert the nearby villages and soon a stream of men, women and children were walking across the fields and down the paths to the brought cows, sheep, goats donkeys, dogs and poultry to be treated with deworm ing medicine and vaccines by the army veterinarians who set up outside the school. makeshift clinic. Some

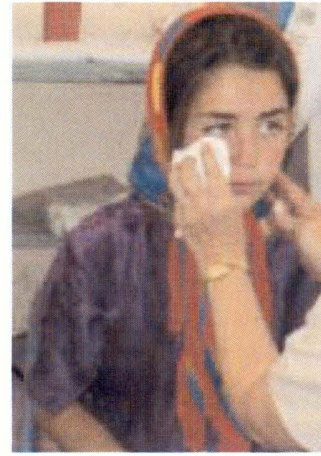

At the school, female nurses and a physician's assistant treated a steady stream of women and children for body aches, stomach pains, indigestion, eye infections, joint pains, low iron and the like. Male doctors from the U.S. and Afghan National

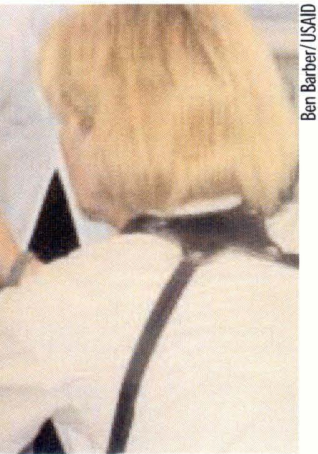

Army treated men in a separate room for similar complaints. Each doctor had a translator. Patients left the impromptu clinic with bottles of amoxicillin, acetaminophen and other medicines. Some 800 patients were treated by the end of the day.

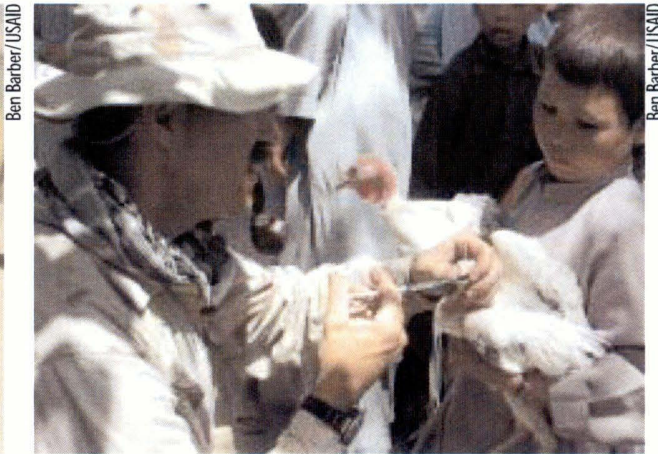

The veterinarians treated 2,000 animals at the village. Here a vet uses a syringe to measure medicine

goats, sheep, donkeys and dogs, giving de-worming medicine and vaccinations.

into a chicken's beak. The

vets also treated cows,

World Bank announces $\$ 108$ million interest-free lo an

USAID announces $\$ 60$ million basiceducation program
Customs collection begins

USAID prints 8.7 million textbooks
UN demobilization program begins

Refurbished Rabia Balkhi Women's hospital re opens in Kabul

First computer ne tworking class gradua tes from Kabu I Univer sity 


\section{Reconstruction Accelerates}

Private and State projects

build hotels, roads, schools

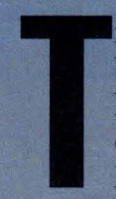
bricks and gravel speed over the newly-paved highways into Kabul and other cities as Afghanistan rushes headlong to recover from three

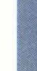

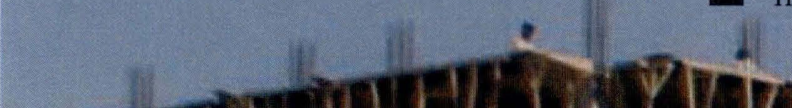

Child census, polio vaccination campaign begin
Spanish forces die in plane crash
USAID provides seed and fertilizer for 100,000 farmers decades of war and stagnation

On the outskirts of Kabul, traffic slows to a crawl in the colorful chaos of fruit markets and taxi stands crowding the streets because sidewalks are dug up for new pipes.

A forest of reinforced steel bars probes the skyline as building after building - most of them privately built hotels, houses and

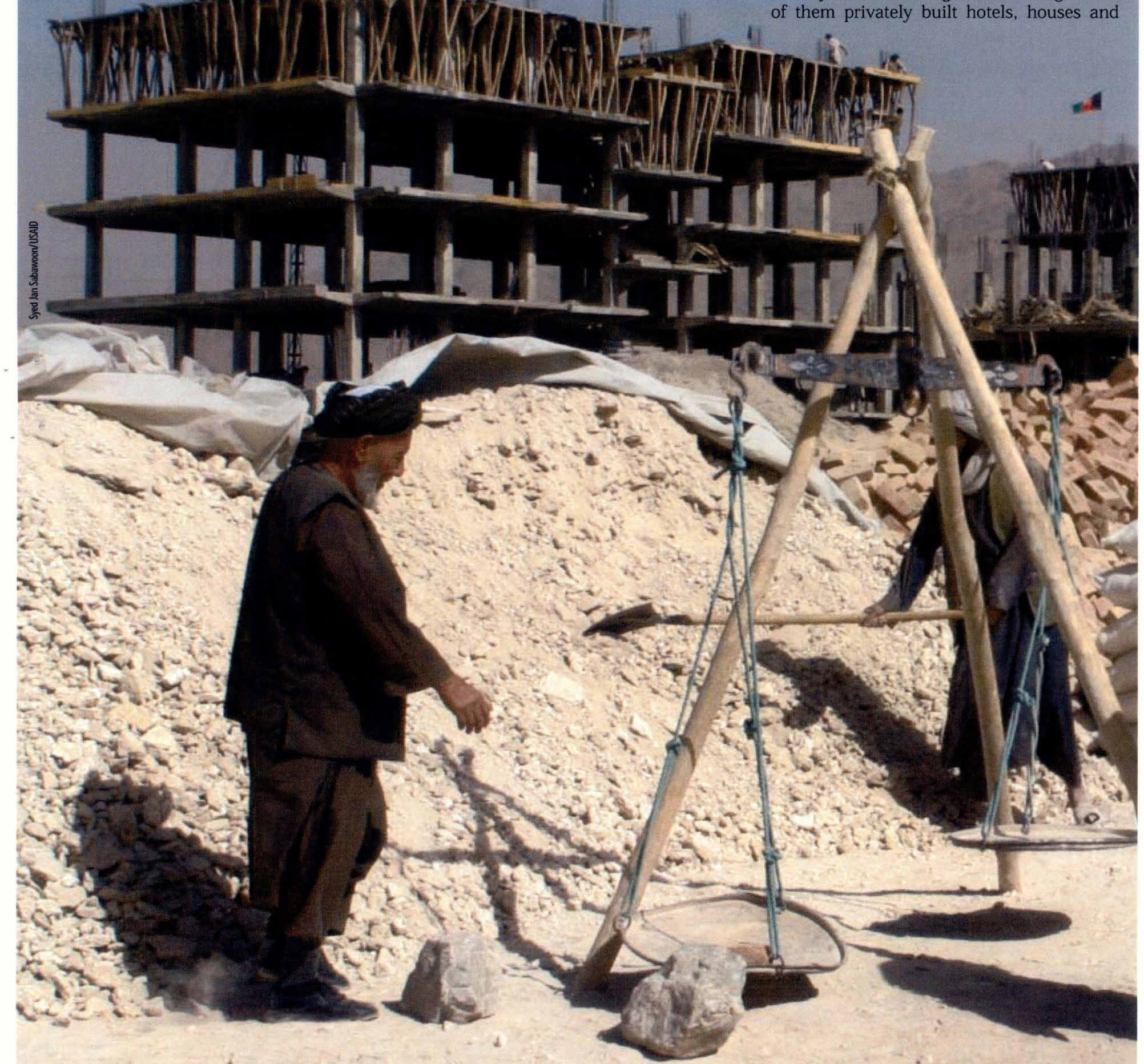

Asian Development Bank approves $\$ 150$ million in frastructure lo an

Afghan Constitution Commission sets up offices in every province
Int. Olympic Commit lifts ban on Afghani:

Niswan Girls' Sch opens in Gardez 


\section{Ring Road Sealed}

The foundation for reconstruction was the repair of the country's most important highway, running 300 miles from Kabul to Kandahar. The road was originally paved in the 1960s by U.S. foreign aid grants. But during the anti-Soviet war and the period of factional fighting and Taliban control, the road deteriorated into a bone-jarring series of potholes and washouts, damaging vehicles and slowing traffic to less than 10 miles per hour in places.

Today, the ribbon of new asphalt winds through the hills south of Kabul en route to Ghazni, makes a final bend, before streaking southwest straight as an arrow over flat land towards Kandahar. On either side, villages drape their greenery over the landscape, nourished by wells, canals, and the ancient underground karezes carrying water hundreds of miles to fields. The road is used by farmers sending ripe tomatoes and melons to Kabul's markets, by women heading to maternity hospitals to give birth, by students beginning the semester at Kabul University.

The next major project is rebuilding the road from Kandahar to Herat. On the road north from Kabul to Mazar-i Sharif, repairs are underway at the 11,000 foot high Salang -Tunnel through the Hindu Kush Mountains-a chokepoint linking the North and South and an eventual trade link between South and Central Asia. Most of the Afghan people live within 30 miles of the Ring Road, which links its four major cities.

But not all the reconstruction projects are huge ones such as the Ring Road or, for example, the $\$ 9$ million Women's Dormitory nearly completed at Kabul University. The Ministry of Reconstruction and Rural Development (MRRD) says that 4,000 communities have formed local councils, or shuras, which decide on projects and are given small grants of about $\$ 30,000$ to $\$ 60,000$ to carry them out. Bridges, roads, culverts, schools, water systems, and training centers for weaving and tailoring are among these projects. A visit to Jalalabad and the villages around it give one a sense of the reconstruction as it takes root in the countryside where most Afghans live.

Standing down in the trench where he is installing a hydroelectric generator, Ulam Habib, 40, puts a final dab of cement on his trowel, lays yet another brick, and stands up to greet a visitor to his village in the Kama District of Nangarhar Province near the Pakistan Border.

"This project will be great," he said, looking over the swift flow of water through a cement channel as it passed through a diversion around the construction site. "It will give us fans to get rid of the mosquitoes that cause malaria. We will get lights, freezers, washing machines."

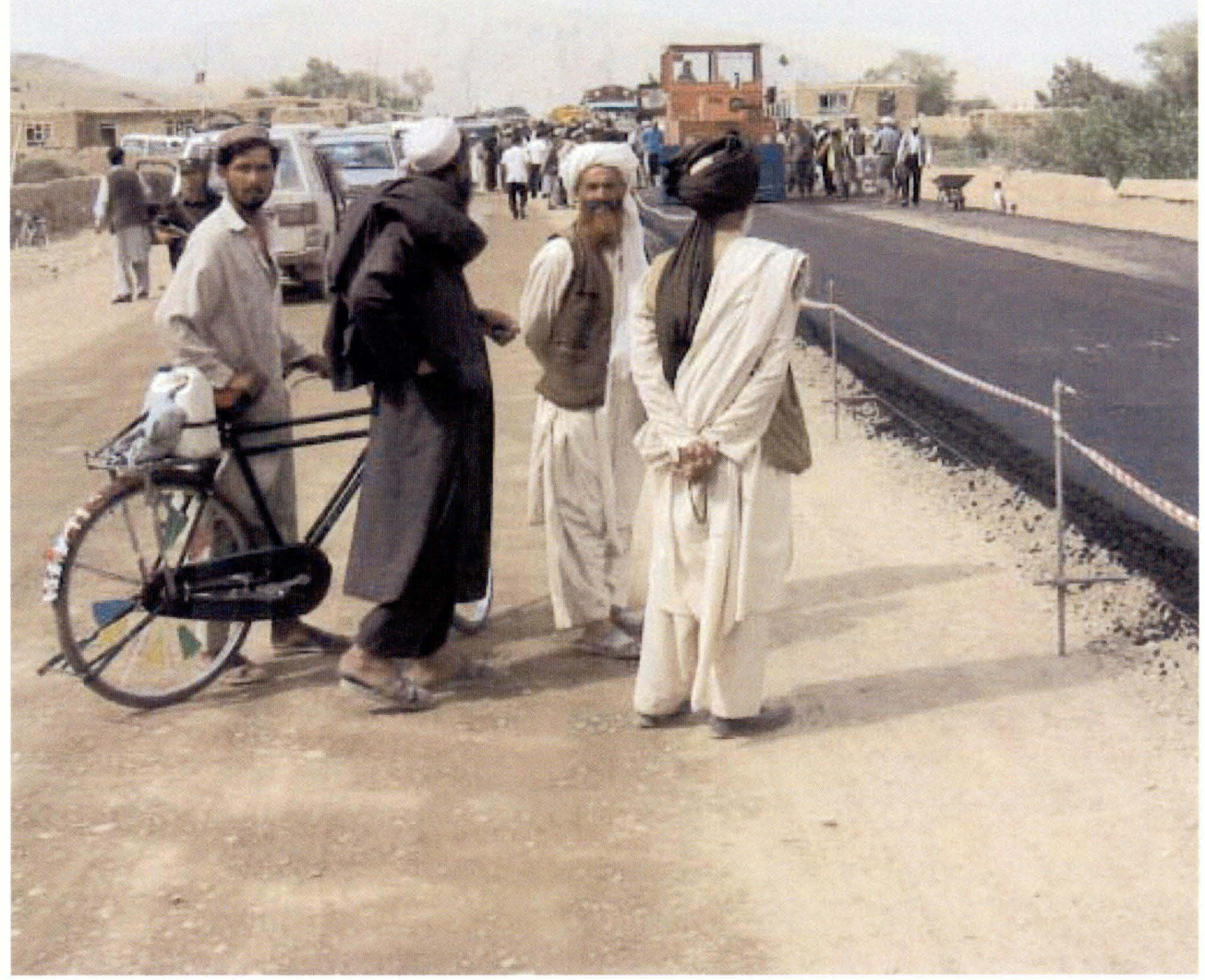

The Kabul to Kandahar road The 300-mile road, linking has been one of President the major population cenKarzai's highest priorities. ters of the country, was re-

The 10 kilowatt generator serving about 3,000 people at a cost of $\$ 13,000$ is typical of thousands of small projects funded by the U.S. civilian and military assistance programs. A few kilometers away, a wide canal funnels swift waters past fields full of corn and vegetables. A \$2 million USAID grant paid for dredging 61 kilometers of the canal carrying water from a dam on the Kunar River and fixing metal gates that regulate the flow into side channels reaching farmland.

In Kama itself, a U.S. grant of $\$ 160,000$ is paying to build a district center which will house the local government offices, now based in a few rooms at the school. Workmen mix and pour cement as the project takes shape inside ancient-looking ruined mud walls.

Over a lunch of nan flat bread and stewed meat, USAID Program Officer Michelle Parker, based at the Provincial Reconstruction Team in Jalalabad, tells Kama deputy governor Mohammad Ali that the Agency is willing to pave the center of Kama and other district centers. Ali smiles and says the paving will help cut down on dust, disease, water-borne parasites, mosquitoes, and other problems.

A few miles away, grading has begun on the 122-kilometer road linking Jalalabad opened in December, 2003.

USAID had originally built the road in the 1960 s.
Cabinet approves law permitting political parties
Congress approves $\$ 1.2$ billion Afghan reconstruction plan

First FM radio station opens
Disarmament, Demobilizatio and Rein tegration program launched in Kunduz
USAID begins $\$ 100$ million health project and Asmar near the Pakistan border. "It used to take 30 minutes to get to the Kama Bridge south of here-now it takes 10 minutes," said Sharifullah, 20, who lives near site where yellow machines have been grinding the abundant stone of the region into gravel. Cars now reach 80 kilometers per hour on the road. Grading and paving are being carried out by the U.N. Office for Project Services (UNOPS) and by contractor Louis Berger over the next 12 months, said Berger engineer Sardar Ahmed.

Around the country, construction of schools, clinics, government buildings, wells, canals, drains, and roads is changing the face of the country. The MRRD says that under one program alone, 1.5 million people have benefited from 204 water and sanitation projects in 2003 costing \$11 million. This included 3,387 wells, 1,712 water tanks ply networks. Funding came from the U.S government, which is spending $\$ 2.3$ billion in 2004, as well as UNICEF and Japan.

Other major projects include new bases for the new Afghan National Army. These will be built by the U.S. Army Corps of Engineers, with Afghan workers hired through local contractors. (see page 18).

Among the largest private construction 


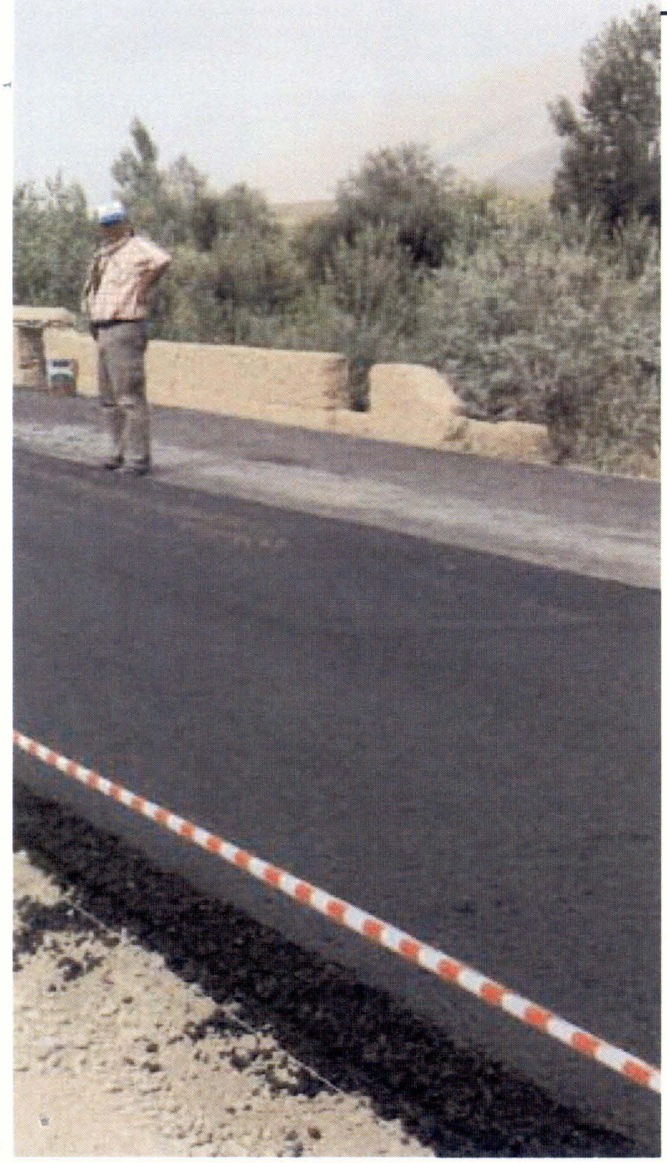
project. Roads, schools,
health services, and water

Afghans discuss local aid
project. Roads, schools,

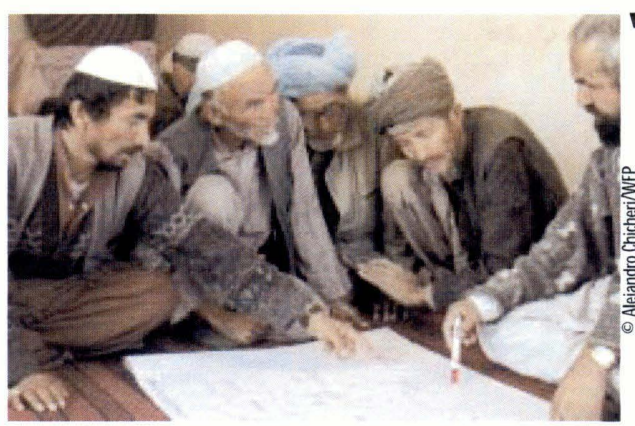

projects are the most commonly requested.

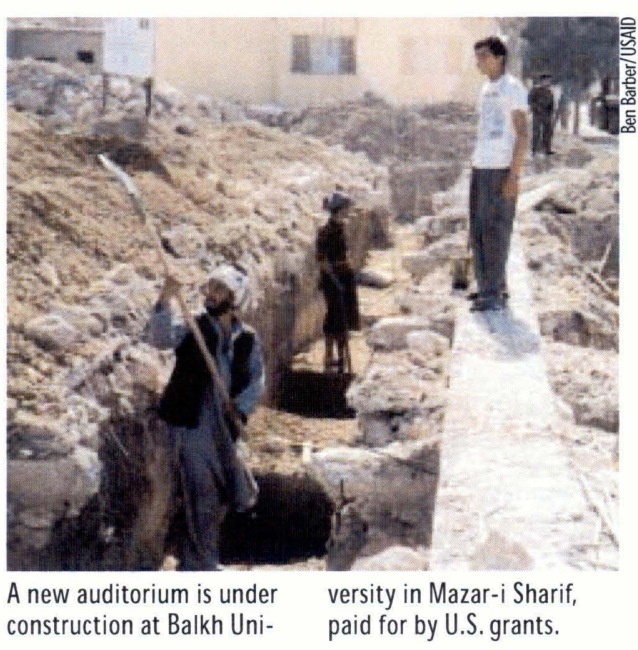

Results

- Repaired, graded and paved 300 miles of the Kabul to Kandahar Road.

- Work begun on the Kandahar to Herat section of the Ring Road.

- Reopened the Salang Tunnel, keeping the main road north of Kabul open during winter. Permanent repairs are underway.

- Hundreds of miles of secondary roads are being graded or paved.
- Completed over 6,100 water-related projects, including wells, irrigation canals, karezes, dams, reservoirs, and potable water systems.

- Thousands of smaller reconstruction projects completed and underway including district centers, schools and clinics, providing jobs for thousands of Afghans.

- Built 119 markets in key villages and cities throughout the country. projects are the new Hyatt Hotel and the new U.S. Embassy Chancery and Apartments rising opposite each other in the Wazir Akbar Khan neighborhood of central Kabul. They're being built by the Afghan Reconstruction Company, which was formed by several Afghan-American investors and Turkish contractors and has already built major portions of the Ring Road.

The whole range of reconstruction can be seen at one small village in the Shomali Plains north of Kabul, which was badly damaged by warfare. While U.S. assistance paid for a new clinic and the foundation has been laid for a new school, local people returning since the Taliban was overthrown are building on their own.

Across from the clinic, builders mix and pour cement as they build a three story house, which will include a store, a warehouse, and upstairs living quarters. Farther down the twisting lanes of the village, a dozen workmen sit under a tree sharing their lunch. Next to them opens a large foundation for a mosque they are building. "Now we have the clinic," said the head of the builders. "Soon, the school will be done. When we have the mosque as well, then everyone will return and we will have a normal life again."

\section{Water and Health}

Nothing is more vital to people's health than clean water. Millions of Afghans face sickness from unclean water, a problem made worse by years of drought. CARE has been providing clean water to 600,000 people in Kabul under USAID projects even under the Taliban. Returning refugees have tripled the city's population to 3-4 million. Many will lack clean water, says CARE's Dad Mohammed Bakeer.

Straining to meet the new demand in August, a yellow backhoe digs a trench along a major avenue near the CARE water treatment plant, searching for a pipe leading under the street to another well. Water from the plant is pumped up to a reservoir on a

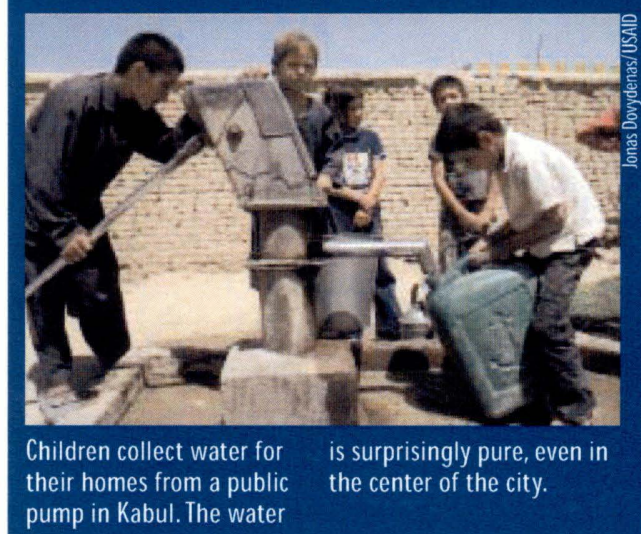

"Now we have the clinic. Soon the school will be done. When we have the mosque as well then everyone will return and we will have a normal life again."

Head of builders at mosque project, Charikar
AINA, new TV Station, begins broadcasting in Sheberghan
Proposed constitution presented to Karzai
Cen tral Government linked to all 32 provinces through USAID codan radio project
USAID completes

Kabul-Kandahar road hill above the city. At one tap, a dozen children stand in line to fill containers for their households. One young man, Abdullah, walks up and says he'd returned to the country from Pakistan because

"there is freedom, it's peaceful and I wanted to return to my own country.

"How long will I stay in a strange country? Now the situation is very much improved here, thank God." Although he can earn 120 to 150 Afghanis per day ( $\$ 2.50$ to $\$ 3.00)$ on construction work, housing is hard to find with all the new people moving into the city he said.

CARE also works on the drains needed to remove waste from the city and drain away breeding pools for mosquitoes that spread malaria. Bakeer brings a visitor to a vacant lot where widows earn $\$ 2$ per day separating organic from inorganic trash cleaned out of a drainage ditch. "This job has a bad smell but we enjoy it because we clean up disease and smells," says Fazil Rahman, 65, who was elected by the neighborhood to a council overseeing the cleanup.

Says teacher Abdul Hai, 40: "In 10 years this is the first time people come to clean this area. There is a change in attitude. Now people don't put rubbish in the street. We are becoming self-reliant."
UN staffer killed in Ghazni
3.4 million children receive polio vaccine 
velopment. The $\$ 39.9$ million project focused on fiscal, banking, and trade policy reforms.

But you don't need to dig into the ledgers of the Ministry of Finance to see the changes. Hotels, apartments, supermarkets, and other buildings financed by private investors are rising along many of Kabul's main roads. It's a sign that businessmen believe the financial system is strong and that they will be able to recoup their investments.

Another sign of progress was the March 31, 2004, Berlin Donor's Conference, in which the United States, Japan, the World Bank and other donors pledged $\$ 8.3$ billion toward the reconstruction of Afghanistan by 2007.

The Berlin meeting was followed by the Afghanistan Development Forum (ADF) in Kabul April 22-24, where six new National Priority Programs were announced.

Plans call for: industrial parks (these have already been built); factories to dry and export fruits; exploitation of minerals; production and marketing of handicrafts, especially carpets; textile factories; and a smelter to turn tanks into construction rods.

Other potential revenue sources are: a pipeline to move gas from Turkmenistan across Afghanistan to Pakistan and India, and overland transport from South to Central Asia and Russia.

Interim President Karzai said in Washington on June 14, 2004, that the Afghan economy grew 30 percent in 2002 and 25 percent in 2003. He said he expects the economy to grow at 15 percent per year through 2008.

The goal, he told the U.S. Chamber of Commerce, is to lift per capita income of Afghans from $\$ 150$ per year to $\$ 700$ per year within seven years.

\section{Investing in Agriculture}

The chugging sound of a tractor turning the soil comes through the heat of the afternoon in a village outside Jalalabad, capital of Nangarhar Province. The crops grow thick and tall in the fields: tomatoes, potatoes, onions, and wheat. While much of Afghanistan is arid rock and sand, Nangarhar Province is irrigated by the Kunar and Kabul Rivers, bringing melted snows off the Hindu Kush mountains.

Malik Mohammad Ayub, 50, a landowner in Akhund Village, stands in front of a sign announcing a U.S. program to distribute seeds and fertilizer. He recalls that "there was a lot of fighting here-against the Russians and among the mujahidin.

"Now, peace has arrived. The current

government brought peace. But we still want our road fixed."

Over and over, in Ghazni, Balkh, Nangarhar, Parwan and other Afghan provinces, rural people tell a visitor that roads are the key to improving their lives. A 130-kilometer road is being graded in preparation for paving just across the Kunar River from Ayub's village. Already cars and trucks speed at 80 kilometers per hour delivering fertilizer and seeds to farmers and hauling their fruits, vegetables, grain, and goats to the markets in the cities.

Afghanistan suffers from the drought which parched the nation's fields from 1998 to 2002 and once more this year. Combined with the effect of 25 years of war, it has destroyed 50 percent of orchards, 60 percent of livestock and 50 percent of irrigation systems. Some 80 percent of the roads were damaged, five million Afghans fled into exile, government was uprooted, and people turned to growing poppy for opium.

The humanitarian situation was so bad in the final years of the Taliban that the U.S. and other donors provided huge amounts of grain to help Afghans survive even as the Taliban allowed terrorists sanctuaries to recruit, train and plan attacks on America.

Since the fall of the Taliban, many foreign assistance programs have begun to repair roads, provide seed, and give other aid. Among many U.S. and other donor programs, USAID has invested $\$ 153$ million over three years in its Rebuilding Agricultural Markets Program (RAMP). In one year, RAMP has repaired 305 kilometers of canals, improved irrigation for 305,000 hectares of

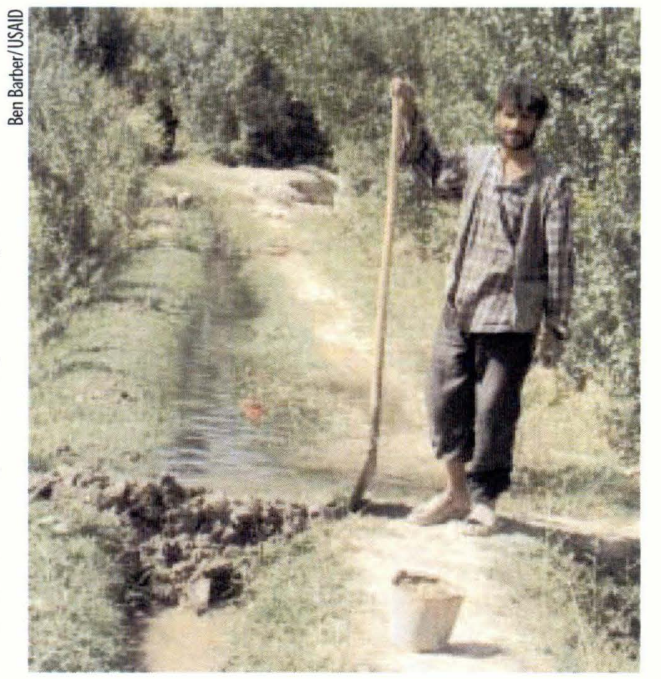

In a village in Ghazni province, a man channels water pumped from a well

\section{Results}

Finance, Industry
Replaced old Afghan cur-
rency with new Afghani
notes worth 1,000 more.

- Upgrading Finance Ministry accounting systems.

- Hundreds of new private buildings going up.

- Industrial parks planned and built.

Agriculture

- Supplied improved seed varieties and fertilizer, boosting crop production by 80 percent.

- Dredged canals, cleaned and rebuilt irrigation systems.

Constructed farm-tomarket roads, lowering prices on commodities.

- Reforming revenue-pro ducing customs collection system.

- Funding alternate crop program to replace poppy.

land, fixed 110 kilometers of farm-to-market roads, treated or vaccinated 2.5 million livestock, and provided extension services to half a million farmers.

In one small but significant project in Jalalabad, aid worker Richard Strand and his team of dozens of Afghan agricultural experts have planted 24 hectares of trees in tight rows under a U.S.-funded programthe Nangarhar Agricultural Development Project-which gave away 115,000 baby trees last year. Peach, plum, apricot, apple, pear, cherry, almond and walnut are some of the varieties grown by Stand, executive director of International Foundation of Hope, an NGO.

"We sent 37,000 trees to Kabul for their green belt," said Strand, who came to Afghanistan in the 1970s and stayed in the region.

\section{Fighting Poppy}

A key goal of agricultural assistance is to end poppy growing, which has become the country's largest source of income at an estimated $\$ 2$ billion. Britain has taken the lead for the coalition forces in fighting poppy, which is grown in 28 out of 32 Afghan provinces, said Sayed Ghulfran, director of the U.N. sponsored agency Narcotic Control and Rehabilitation of Afghanistan. This year's crop is expected to yield 3,600 tons of opium, enough to produce 75 percent of the world's heroin. Last year, about 3,400 tons of opium was produced.

Anti-poppy efforts fall into four main areas: alternate livelihoods (providing farmers with roads, seeds or jobs that can replace income from opium); eradicating crops in the field; interdiction (capturing drug dealers, destroying laboratories and shipments); and enforcement of anti-drug laws. 


\author{
Ex-Militia fighters take up \\ new lives, returning to \\ school and learning trades
}

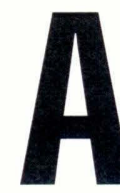
bout 20 kilometers from the center of Kabul, along the road to Jalalabad and the Pakistan border, 800 newly-trained Afghan National Army (ANA) soldiers raised clouds of dust as they sprinted in unison in their green uniforms.

It was the latest group of graduates from the Kabul Military Training Center, built and maintained by the U.S. military under a $\$ 750$ million plan to prepare a national force capable of replacing the militias that ousted the Taliban in 2001, with U.S. and other military support.

"With the help of the coalition we are making national unity and bringing Afghanistan together," said Sgt. Mohammed Yussuf, 26, a soldier for 21 months in the new army.

Standing at the edge of the parade ground while the newer recruits marched, sprinted and received awards from U.S. and Afghan generals, Yussuf recalled that "before the ANA there was some ethnic discrimination-you were seen as a Tajik or Uzbek or Hazara or Pashtun.

"Since the establishment of the ANA, we live together as brothers. We think we are one nation and one army. The army is the heart of the nation. I want to serve."

Yussuf, who earns $\$ 145$ per month and lives with his wife and two children in Pul-i Charki nearby, has put his finger on the key to Afghanistan's future: creation of a strong national army formed from all major ethnic groups to spread rule of law from Herat to Kandahar to Mazar-i Sharif. Units are 30 percent Pashtun, 30 percent Tajik, and 10 percent Uzbek, Hazara, Turkomen and other minorities.

The ANA will replace the ethnic warlords who fought against the Soviets and then against the Taliban. It should also allow the 18,000 U.S. troops and 8,000 NATO troops in the International Security Assistance Force (ISAF) to eventually go home, leaving the Afghans in charge of their own security.

Since it was created two years ago, the ANA has trained and deployed 14,000 troops at bases built by the U.S. and other foreign agencies around the country. The U.S. Army Corps of Engineers is completing barracks, dining halls, and other facilities at a large

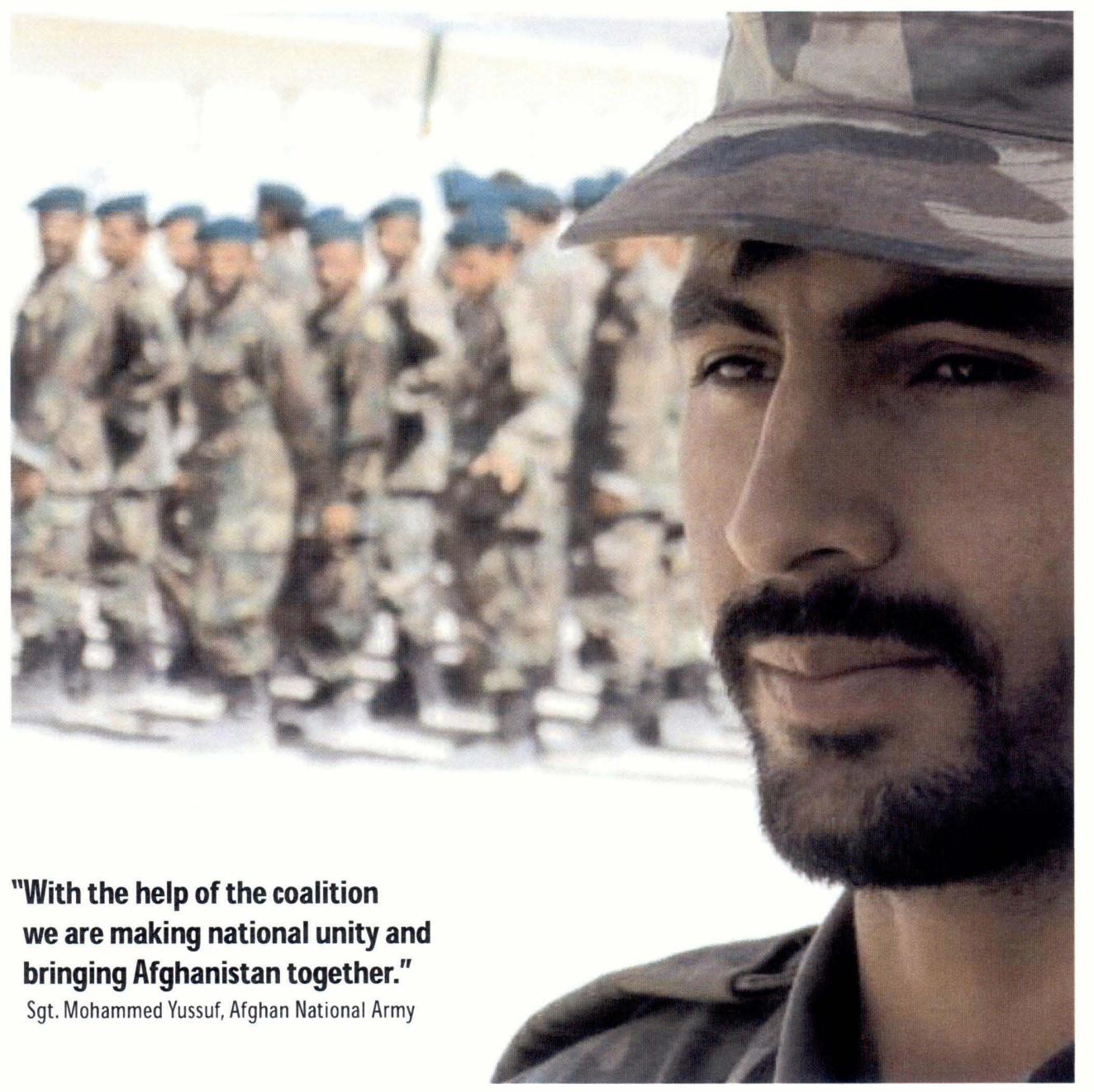

Sgt. Mohammed Yussuf outside Kabul where 800 stood on the parade ground new Afghan National Army soldiers held a graduation

base in southwestern Kabul on a hill overlooking the shattered palaces, office buildings, and homes left from internecine warfare among regional militias after the Russians pulled out in 1989. The ANA goal is to reach some 70,000 troops in another two years.

In the 1960s, Afghanistan was a poor country, but a foreign visitor could travel its length and breadth, day and night, without fear. After 10 years of war against the Soviet Union and another 10 years of rule by warlords and repressive religious zealots, Afghanistan is returning to the more peaceful days of its past.

Trucks, buses, motorcycles, donkey carts, and people on foot crowd the main roads and the narrow lanes of cities and villages. Shopkeepers lean their melons and other goods against outdoor displays. Moneychangers hold up fistfuls of the new ceremony after their train-

ing course ended.

Afghani notes-all without a single rifle to be seen.

According to a poll released July 27 , 2004 by the International Republican Institute (IRI), some 77 percent of Afghans believe overall living conditions have improved in the past two years, and 90 percent say conditions are better than five or ten years ago.

Some 64 percent said law and order has improved, but an equal number said security remained their paramount concern, mainly because the remainder of the warlords still cling to power. Ironically, while those powerful ethnic leaders in the outlying provinces sometimes abuse the law and fight among themselves, they also have the power to control the holdouts of Al Qaeda, the Taliban, and Gulbuddin Hekmatyar's militia.

Those groups continue to launch attacks
First commercial television channel starts
US Congress passes $\$ 25$ billion emergency request for Afghanistan, Iraq
Electoral workers killed near Jalalabad

USAID program treats 2.3 million livestock 


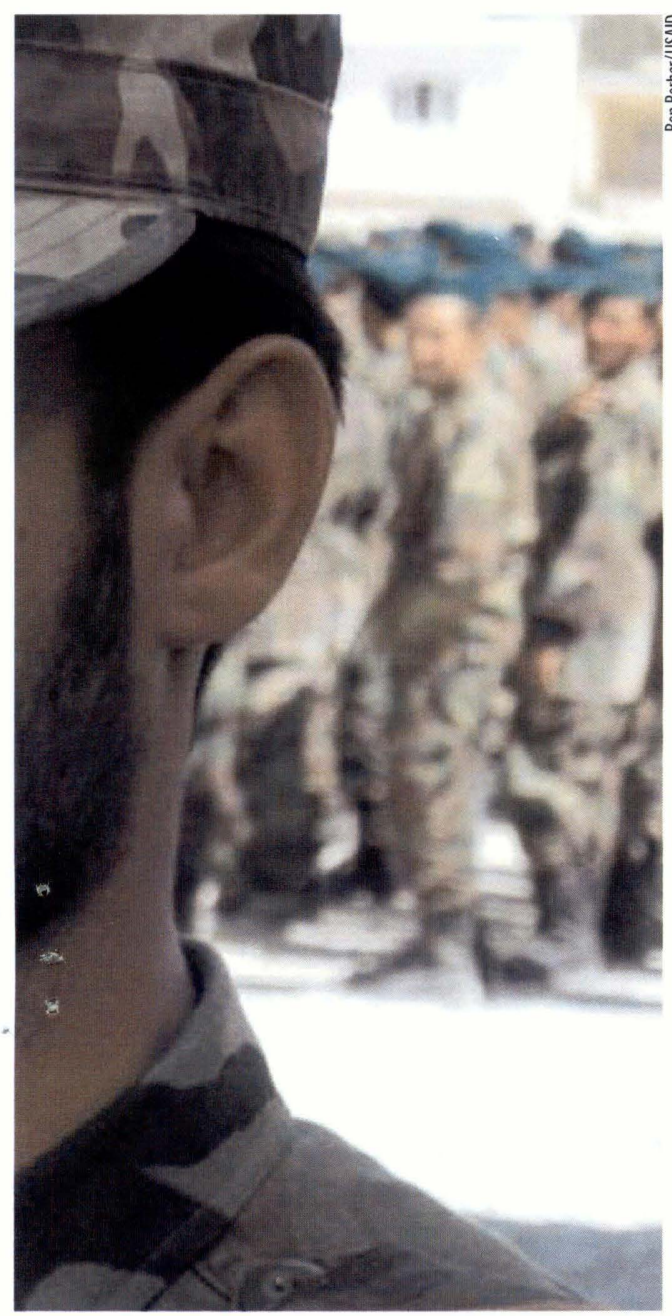

from remote hideouts along the Pakistan border and elsewhere, but appear to have little support among the Afghan people, according to polling data and random interviews.

The IRI survey reported that despite Afghanistan's ethnic diversity, 96 percent said their identity was "Afghan" rather than a specific ethnic group. The survey interviewed 2,378 voters from across Afghanistan and was funded by USAID.

So far, more than 25,000 Afghan National Police have been trained by U.S., German, British, and other trainers under a $\$ 160$ million foreign aid program. One unit was training with U.S. soldiers in the more than 100degree sweltering heat at a base in Jalalabad this August. In addition, the ANA is growing. Border and anti-drug police units are also being trained.

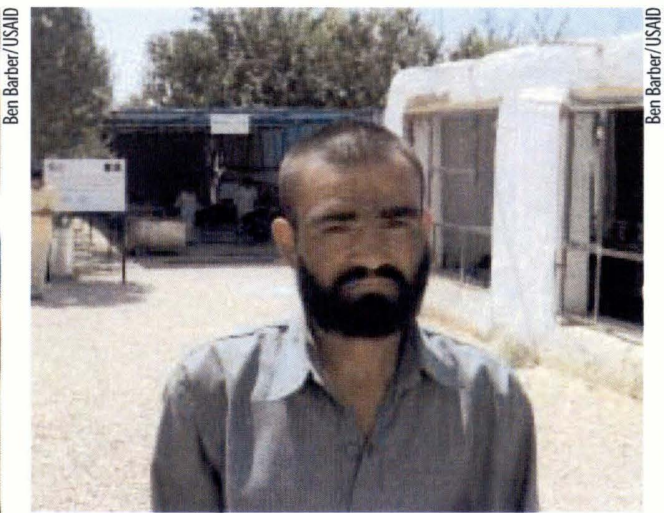

"I am done with fighting. I personally could not find any benefit from the fighting except looting and destruction. I fought for 12 years. Most of my friends disappeared."

Mirwais, who uses only one job training after turning in name, fought for 12 years with an Afghan faction and now is taking literacy and

\section{Disarmament, Demobilization, Reintegration}

Establishing peace requires programs to disarm the militias, train them for peacetime employment, and find them jobs.

Mirwais, 30, stepped outside of his literacy class in Mazar-i Sharif run by the U.N.'s International Organization for Migration (IOM), to explain why he is one of nearly 13,000 militia fighters - of an estimated 60,000 - who have turned in their weapons.

"I am done with fighting," said Mirwais, who hopes to learn carpentry. "I personally could not find any benefit from the fighting except looting and destruction. I fought for 12 years. Most of my friends disappeared."

IOM, using U.S., Japanese, and other donor funding, first shows the militia fighters a video thanking them for serving their country by defending it against communists and then against the Taliban. It says that now that peace has come, they must lay aside their weapons and join the effort to rebuild their country.

After disarming and demobilizing, the ex-combatants need help to reintegrate into a peace-time economy, so IOM has set up training centers, funded by USAID and others, to teach six-month courses in literacy, carpentry, carpet weaving, agriculture, welding, tailoring, auto mechanics, and other trades. Ex-fighters are paid $\$ 30$ a month to sustain their families and some receive bicycles to get to the training centers.

\section{Results \\ 12,000 fighters hand- and deployed in the ed in weapons and Afghan National Police joined literacy and job and units controlling training programs. borders and narcotics. \\ - Heavy weapons being handed in and stock- piled; warlords and armed factions increas- ingly accepting political competition. \\ - 14,000 soldiers in new Afghan National Army have been trained, equipped and deployed to bases around country. \\ - $64 \%$ of country says law and order has im- proved. \\ - Despite threats by Taliban holdouts and targeted violence, Afghans have held two Loya Jirgas, adopted a constitution, and creat- ed an interim govern- ment. By September, 2004, 10 million voters were registered as the October presidential \\ - 25,000 Afghans have been trained, equipped}

And while individuals lay down their automatic rifles-often at the urging of their former commanders-militia leaders have been turning in the heavy weapons. In August, it was announced that all heavy weapons had been removed from the capital, a major step toward complete disarmament.

Meanwhile, about 18,000 U.S. troops patrol the mountains of Asadabad and the deserts of Paktia where militants launch attacks on girls' schools, voter registration sites, local officials, and other aspects of the new order rapidly taking hold throughout the country.

Some 8,000 troops from Italy, Germany, and 27 other countries in ISAF patrol the Kabul area, with several thousand more troops arriving to help protect the October presidential voting.

In a sign of growing security, more than 10 million people registered to vote despite Taliban and other attacks that killed about 20 people in the past year.

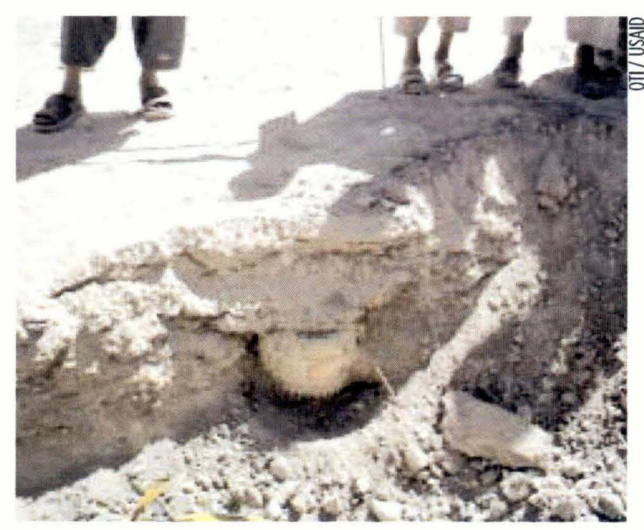

Road crews uncovered a

land mine, one of many left behind by years of war.

Electoral workers killed in Ghazni Méde cins Sans Frontieres
withdraws from Afghanistan
10 million voters registered 


\author{
Afghan and foreign aid \\ workers have left an \\ imprint throughout the \\ country with hundreds of \\ projects improving lives \\ of the Afghan people.
}

\section{Jalalabad, Afghanistan}

\begin{abstract}
raveling through this village in Nangarhar Province, one sees a sign stuck in front of a lush field of wheat: Afghan and American flags flank an announcement of a foreign aid program that supplies seeds and fertilizer.

In Mazar-i Sharif, a similar sign says a school was rehabilitated by U.S. aid. Other signs across the country tell of schools built, clinics under repair, canals dredged, ministries being refurbished. The donors are an alphabet soup of the world's non-governmental organizations, international aid groups, and foreign relief agencies, including WHO, UNOPS, DFID, USAID, UNESCO, WFP, UNICEF, CDC, CRS, CARE, and many others.
\end{abstract}

Coordinated through the interim Afghan

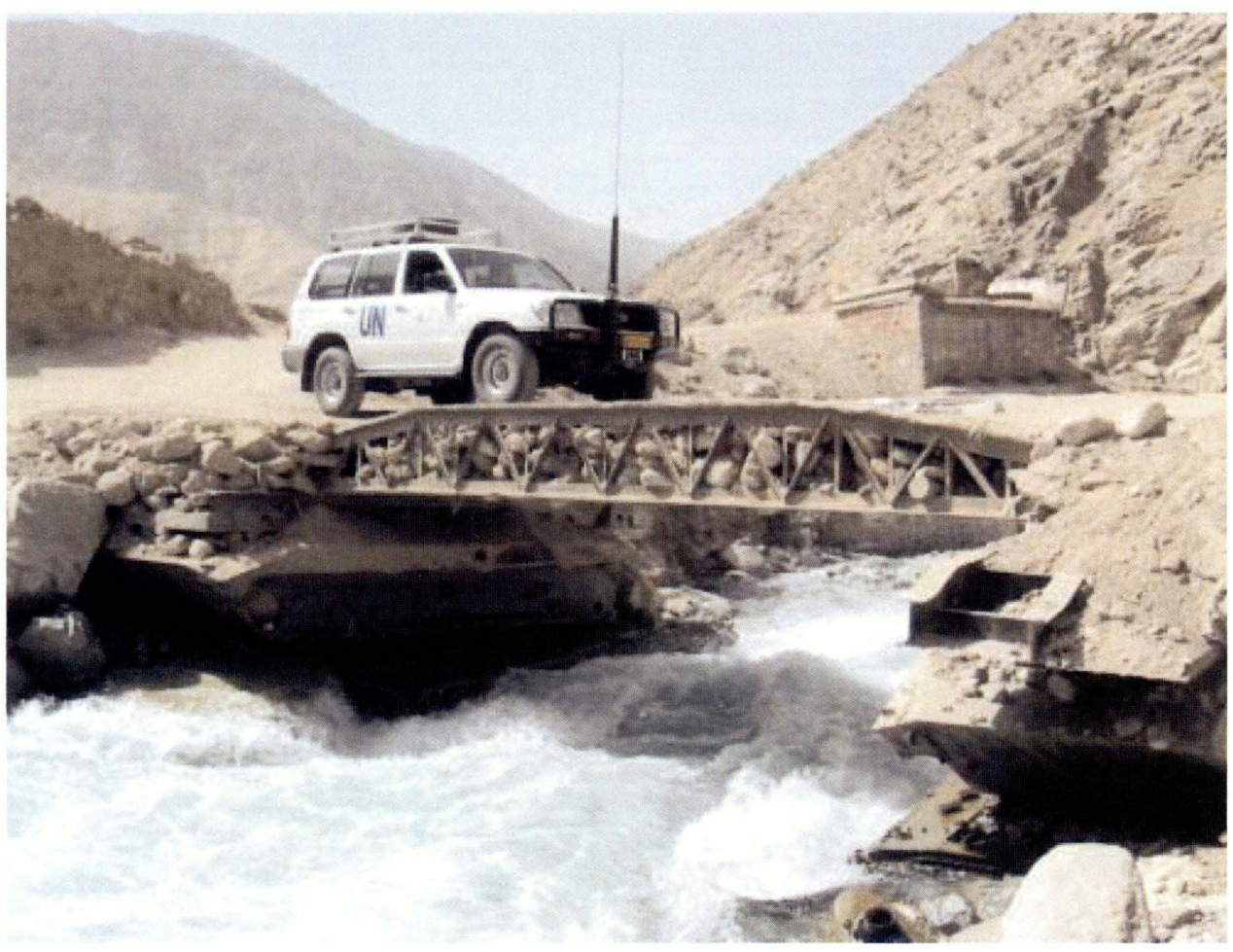

Several United Nations agencies are actively at work in Afghanistan. government, more than $\$ 8$ billion was pledged by 2007, a vast sum for a country with poor roads, a largely illiterate population, that lacks banks, accounting systems, teachers, and professionals.

The Ministry of Commerce, which should help get private business back on its feet, looks like a medieval excavation as staffers and officials carrying files and computer discs walk briskly past laborers patching crumbling walls and replacing glass.

The entire country is undergoing more than a facelift. It is an extensive rebuilding of the way the country functions. Foreign aid workers have fanned out to the most distant villages, where they train women in nutrition, avoiding infections, and keeping children healthy. Afghan army officers are taught by U.S. and British troops both to fire artillery and treat subordinates with respect. Midwives are trained to cut down infant mortality rates.

Because this massive aid is being delivered while some hostile groups remain active, often targeting aid workers to try to sow chaos and undermine the new government, a new concept was created to allow the military to protect aid workers-the Provincial Reconstruction Team or PRT.

American-led PRTs typically consist of

\section{International Contributions}

Berlin, Germany, March 31, 2004

Donor nations here pledged more than $\$ 8$ billion over

for the next 3 years for Afghanistan, exceeding the

Afghan Government's target of $\$ 4.4$ billion for their cur-

rent fiscal year. Pledges included U.S. $\$ 2.2$ billion for

2004; Japan, $\$ 400$ million for next two years; Germany

$\$ 391$ million over four years; EU \$850 million for 2004;

U.K. $\$ 900$ million over five years. The Asian Development

Bank offered $\$ 1$ billion in grants and concessional loans for 2005-2008.

Donors also pledged $\$ 66$ million to register 10 million voters and conduct presidential elections. German, U.S. and U.K. trainers are preparing the Afghan National Army, National Police and Border Patrol. Japan, the United States and the U.N. Assistance Mission to Afghanistan are helping disarm and reintegrate 100,000 Afghan troops by June 2005 .

70-80 troops, a civil affairs team and civilian representatives from the Afghan Ministry of Interior, U.S. Department of State, U.S. Department of Agriculture, and USAID.

At the PRT outside Ghazni, about 100 soldiers are based in a former Taliban school

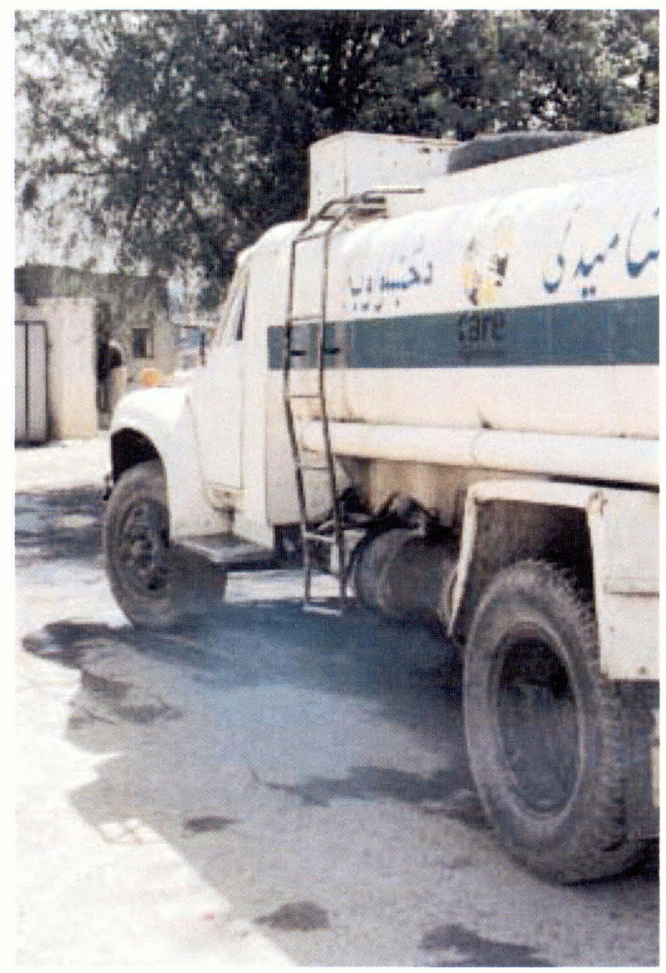

A CARE water truck. Funded water to 600,000 residents jointly by USAID and the EU, of the city since 1993. CARE has been supplying
Karzai replaces governor of Herat
Failed assassination attempt on Interim President Karzai
Pakistan to close refugee camps on Afgh an border 
inside a fortified compound in the desert.

On a typical mission, a team of a dozen vehicles escorted by troops in Humvees files out of the compound, through the city of Ghazni, to a village where medics treat 800 people, and veterinarians treat 2,000 farm animals.

At the Jalalabad PRT, aid workers fasten their bullet proof vests and ride in a small convoy of escort troops to the town of Kama, where USAID workers discuss with local officials progress on a district center under construction, a clinic that needs fans, and plans to pave the town center.

U.S. army civil affairs officers offer quick grants of up to $\$ 25,000$ to fix hospitals, repair roads, supply building materials, dig wells, and help in any ways the local residents and the aid workers agree on.

Some projects are massive: public buildings, water systems, power networks, and support for ministries to train and equip their staffs after decades of neglect. But others are small, so as to reach down to ordinary people and have immediate effect.

PRTs also maintain good relationships with government, tribal, military, religious, NGO, and UN leaders. They monitor political, military, and reconstruction developments and provide security for Loya Jirgas
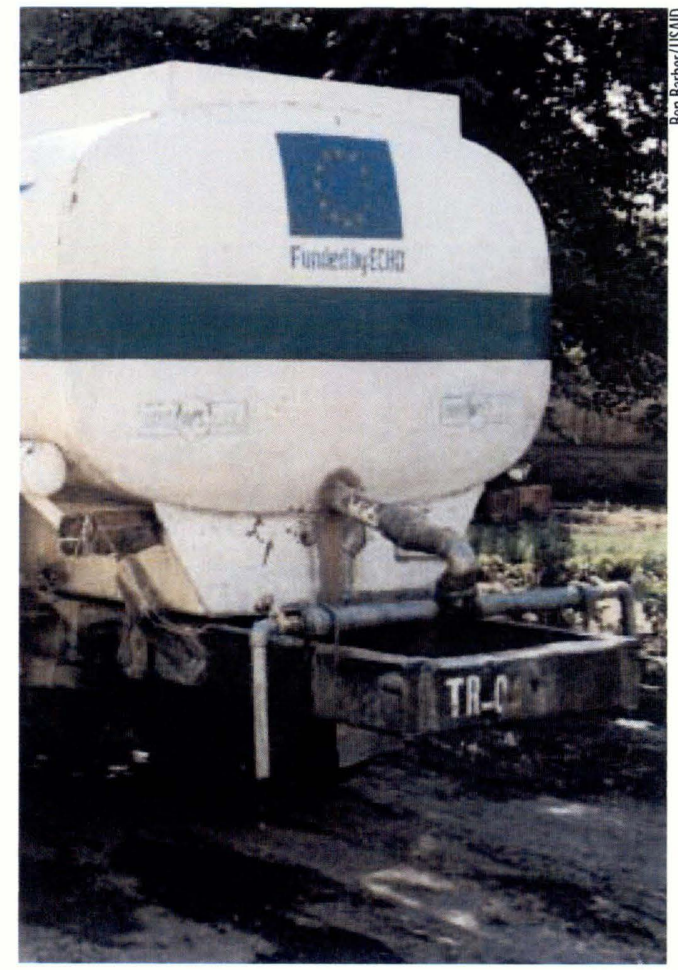

(traditional grand councils), voter registration, and the disarmament, demobilization and reintegration of militia forces.

The PRT staff also assist Afghan National Army and police units and referee disputes between factions.

\section{Impact of Aid}

When asked, Afghans say they are very happy with the repairs and improvements of the last three years. But the need is almost endless. Some provinces still have no electricity, and drought continues to make life difficult in many parts of the country.

Malik Mohammed Ayub stood on the side of the dusty and pitted road leading through the village Akhund, halfway from Jalalabad to Kama, and said that many Afghans feel it is "normal" that the United States and other countries should help Afghanistan recover from decades of war.

"We destroyed our own country for the sake of the world-to remove communism," said Ayub, 50.

Another view was voiced by Ibrahim Shah, 18, a plasterer at a new Afghan National Army base built by the U.S. Army Corps of Engineers.

"I feel very happy and optimistic. The situation is improving here," he said.

\section{Results}

- More than $\$ 8$ Billion pledged by U.S. and other governments over coming years to rebuild Afghanistan's infrastructure, economy, health, education and other sectors.

- Civilian and military teams combine to provide protection to allow aid workers to deliver assistance despite threats by the Taliban.

- Beginning with the improvement of roads, the 75 percent of Afghans who live in the countryside are being drawn into the network of services and opportunities.

Assistance from the United Nations, NATO, multilateral banks and ered to Afghan people through non-governmental organizations.

- Afghans say the aid programs are sensitive to local traditions. other agencies is deliv-

\section{"I think the Americans will let us be whatever we want to be."}

Ibrahim Shah, 18, a plasterer working on a new Afghan National Army base built by the U.S. Army Corps of Engineers.

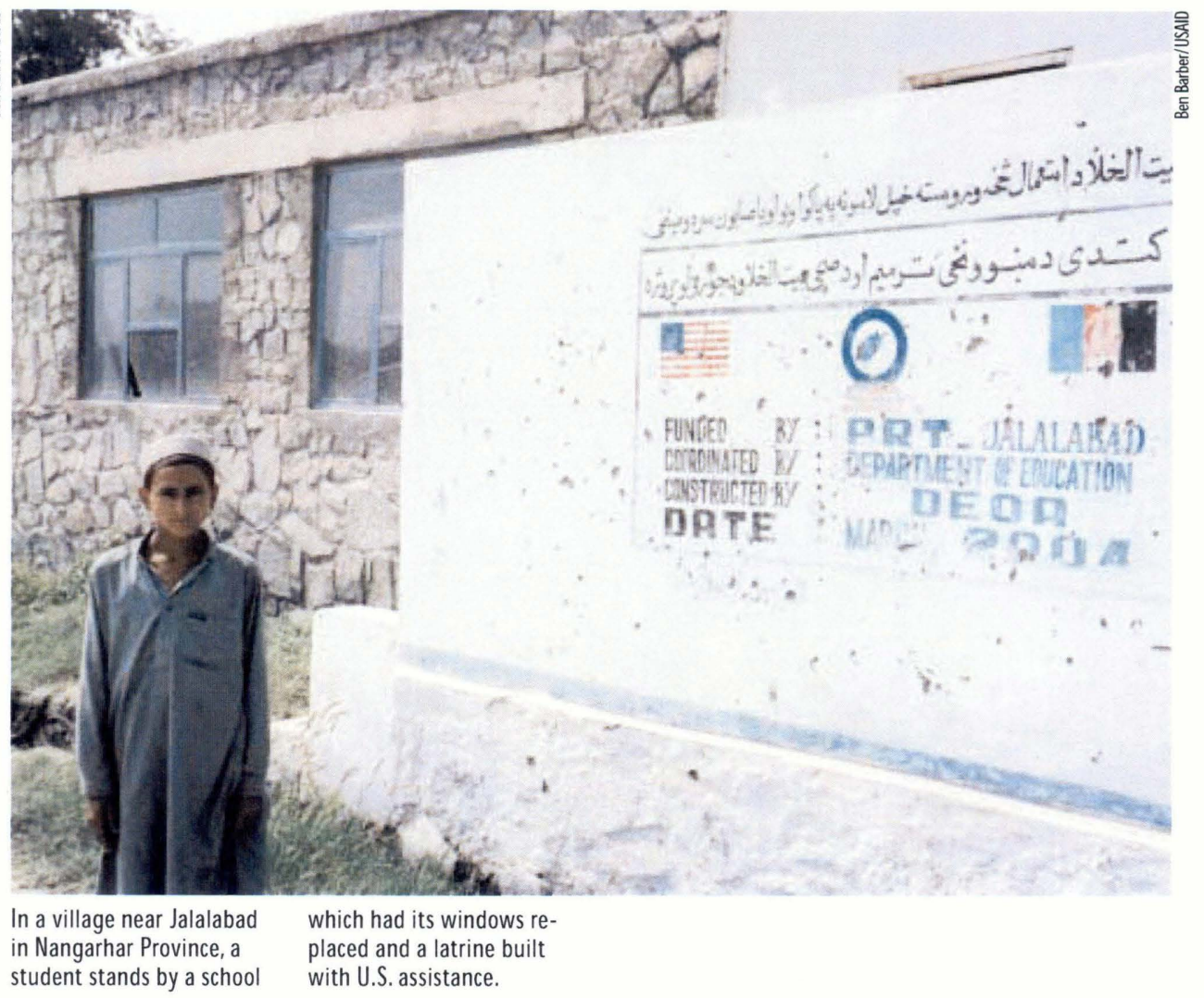




\section{Afghanistan's Place in the World}

Since before the time of

Alexander the Great,

Afghanistan has been a key part of world history.

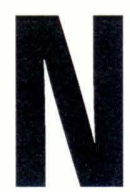

ewspaper editors used to call a story about a remote place that readers knew or cared little about an "Afghanistanism." Recent events, however, have brought troops and aid workers from dozens of countries to this remote land which suffered greatly in the previous quarter century. This is not the first time the country is at the center of world attention.

The Persian leader Darius seized the country in the fifth century $\mathrm{BC}$, and the greatest conqueror of ancient times, Alexander the Great, conquered Afghanistan on his way to the Indus River around 329 BC.

Buddhists took over in the first century $\mathrm{AD}$, carving giant Buddhas in Bamiyan, and Islam reached the country in the seventh century. By the 10th century, Afghanistan had become the center of Islamic power. It was conquered by the Mongol Genghis Khan in 1219, who destroyed its irrigation systems. Around this period, Marco Polo crossed Afghanistan, which was part of the Silk Road linking China with Europe. Tamerlane ruled in the 1400s but faced continual revolts by the Afghans.

The Chagatai Turk ruler Babur took power in the early 1500s and was the first of the Moghul rulers, seizing control over what is now Pakistan and northern India, allowing great freedom for Hindus to practice their faith alongside Islam.

In the 1800s, the Afghans fought and defeated troops of the British Empire, which controlled India. To create a buffer between British India and Russian Central Asia-engaged in a dangerous power rivalry known as The Great Game-the Durand Line was drawn in 1893 as Afghanistan's Eastern border, including a long panhandle called the Wakhan corridor, reaching all the way to China and separating the Russian and
British empires. Unfortunately, it left half the Pashtus or Pathans in Afghanistan and half in British India, later to be carved off as Pakistan in 1947

After the third defeat of the British by the Afghans in 1921, the country became independent, and King Zahir Shah ruled from 1933 to 1973 , when he was overthrown by his cousin Daoud Khan, who in turn was killed in 1978 leading to a Soviet invasion.

The final battle of the Cold War was fought by U.S.-backed Afghan mujahidin fighters against Soviet troops, who went home in 1989. Then, after a chaotic period of factional fighting, Taliban Islamic extremists took power in 1996-turning the Afghan countryside into a nest for Osama bin Laden and his Al Qaeda terrorists until November 2001, when the United States and Afghan allies ousted the Taliban. But great damage had been done.

Of its 20 million people in 1980, five million fled into refugee camps in Pakistan and Iran to escape fighting. Another million people died in the war. Ancient waterworks, villages, herds, and roads were all destroyed or heavily damaged.

The voluntary return of 3.7 million refugees since 2001 shows the strong attachment Afghans have for their land and culture. They are grateful for the refuge given them by their neighbors but quick to say they don't want Pakistan and Iran to try to influence their political, economic, and security decisions.

In fact, there is already evidence of rivalry among Afghanistan's neighbors, especially as it seeks good relations with both India and Pakistan. What analysts fear is that Afghanistan may once more become a place for regional rivals to seek advantages, instead of helping it to recover from the wars, stand on its feet, and improve the education, health and economy as its people so clearly wish. The international community, and in particular the United States and NATOwhich provided troops to defend the Afghans against militants, Taliban holdouts, and terrorists based along the Pakistan tribal areas and other remote regions-have pledged to remain engaged there as long as needed to help the Afghans remain free.

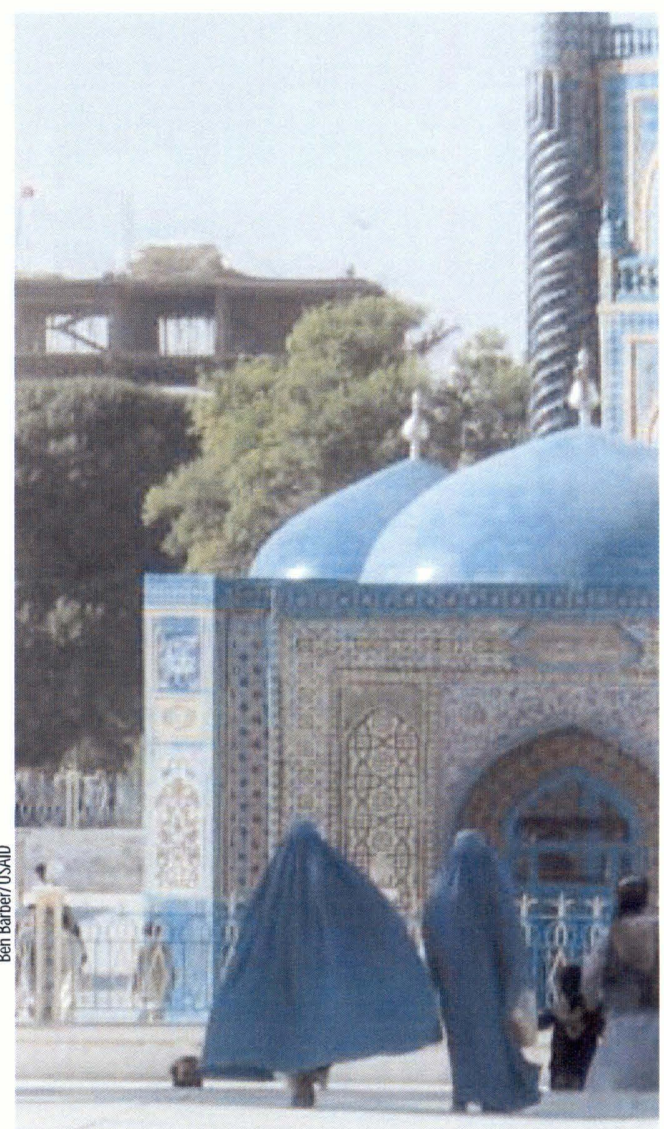

A man walks in front of the 500-year old Blue Mosque in Mazar-i Sharif, said to hold the tomb of Ali, son-in-law of the Prophet Mohammed. The garden next to him, was rehabilitated with international assistance.

\section{"The road ahead for Afghanistan is still long and difficult. Yet, the Afghan people can know that their country will never be abandoned to terrorists and killers. The world and the United States stands with them as partners in their quest for peace and prosperity and stability and democracy."}

President George W. Bush, June 15, 2004

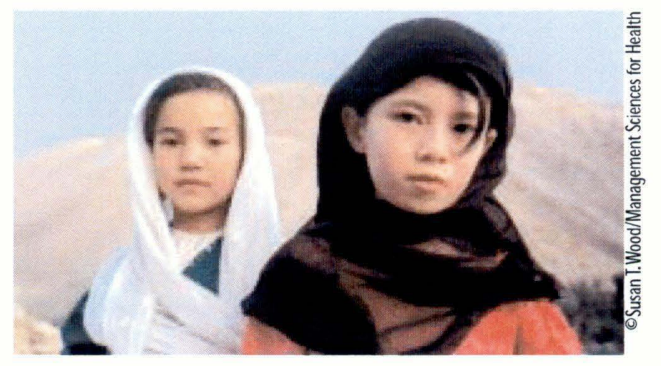

Two girls in Afghanistan. 


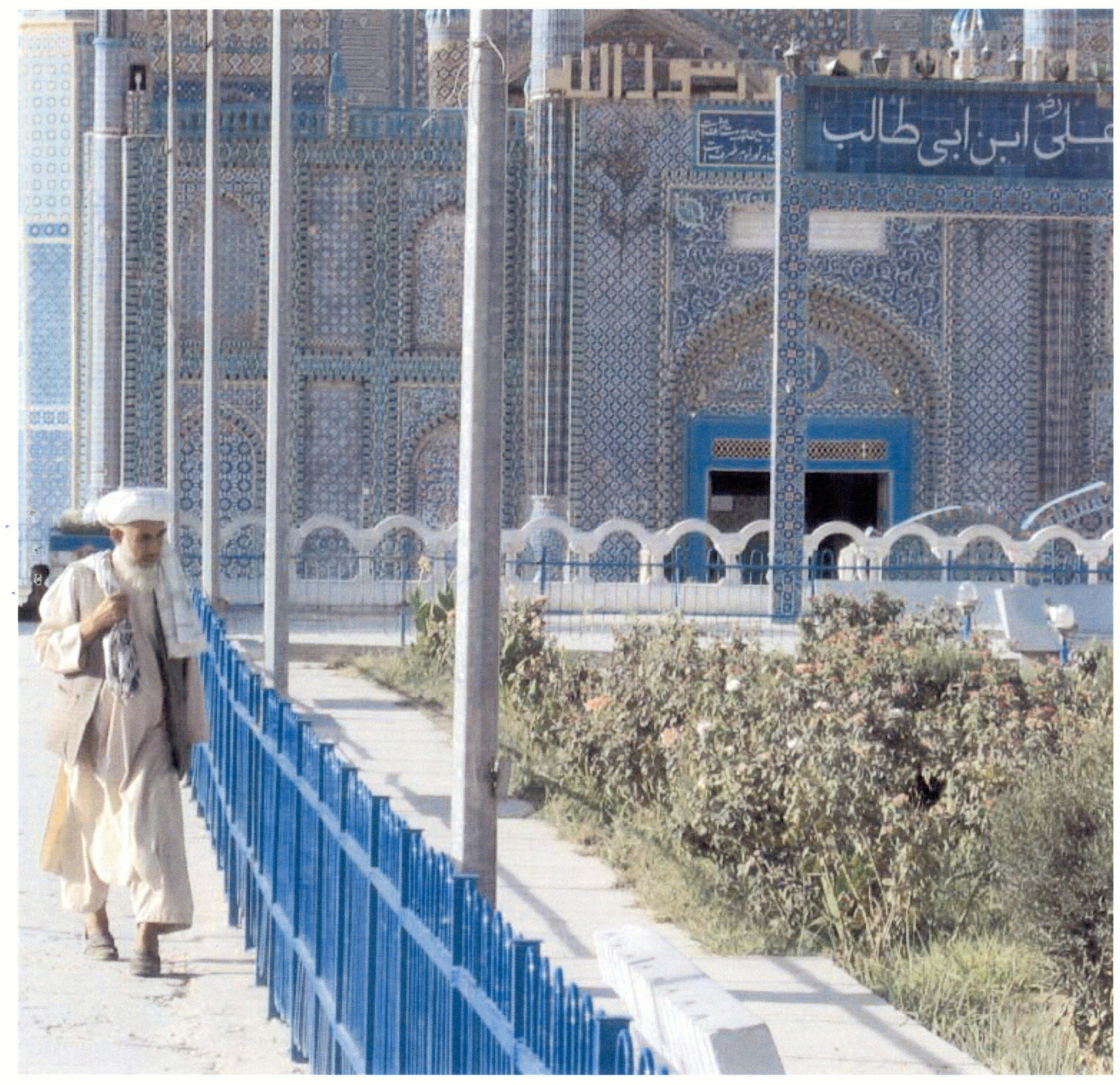

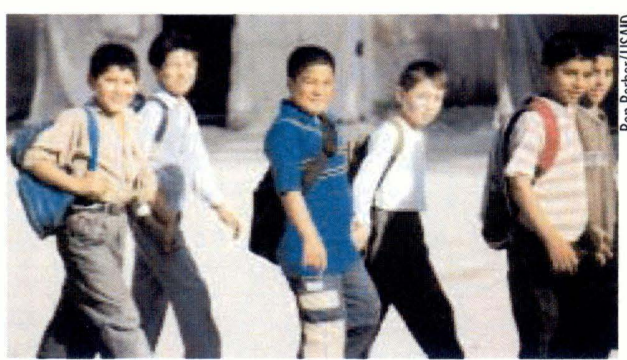

Boys at Bakhter high school

in Mazar-i Sharif where

tents are classrooms for

overflow enrollment.

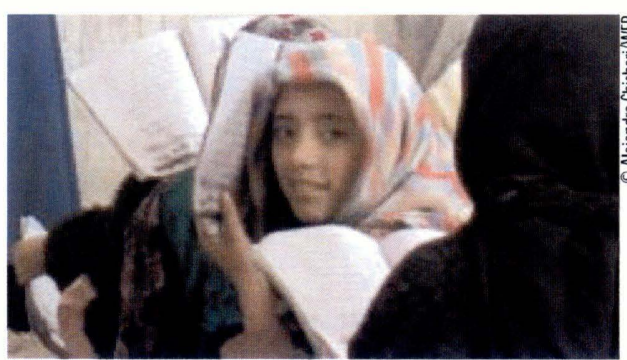

A girl with her text book

looks back over her shoulder

at a visitor to her classroom

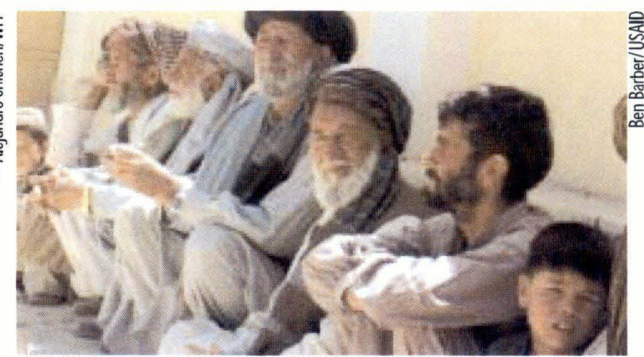

Men and boys await medical treatment at Tormai, a village near the city of medical team set up a clinic for a day, treating 800 people for free. 


\section{Assistance Projects}

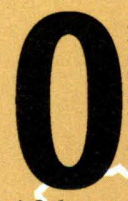

fficial aid agencies from the United States, Japan, Britain, Germany and many other nations have assisted in a great variety of humanitarian and development projects all across Afghanistan since the fall of the Taliban in 2001. The United Nations, World Bank, Asian Development Bank and other international agencies have also given aid. Schools, clinics, water systems, agriculture, sanitation, government buildings and roads are being repaired or built. Many Afghan and foreign humanitarian and development organizations as well as private contractors are carrying out the work in the field. This map shows some of the principal locations where major USAID projects have been completed or are under way.

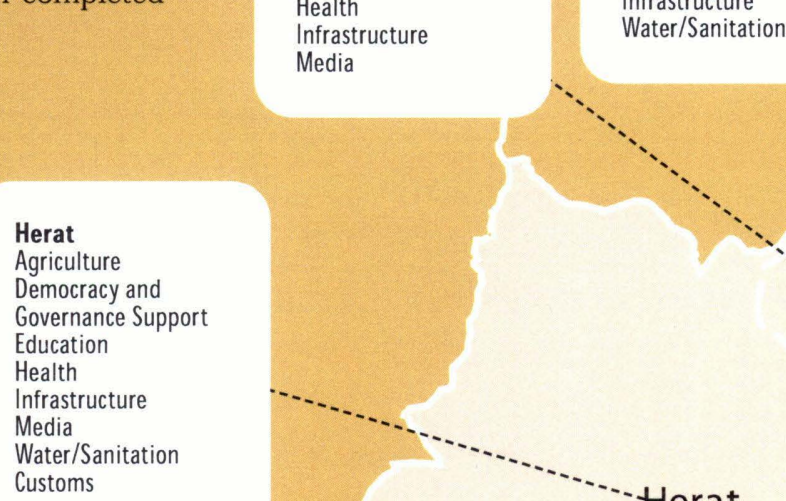

Infrastructur

Media

Water/Sanitation

\section{Farah}

Agriculture

Democracy and

Governance Support

Education

Infrastructure

Water/Sanitation

\section{Faryab}

Agriculture

Democracy and

Governance Support

Education

Health

Infrastructure

Media

Water/Sanitation
Jawzjan

Agriculture

Democracy and

Governance Support

Education

Health

Infrastructure

Media

Water/Sanitation

Customs
Health

Infrastructure

Water/Sanitation

Ghor
Agriculture
Democracy and
Governance Support
Education
Health
Infrastructure
Media

\section{Ghor}

Agriculture

Democracy an

Education

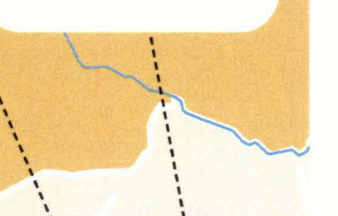

Jawzjan

Agriculture

Democracy and

Governance Support

Education

Education
Health Facilities

Infrastructure

A F G H A N I: Uruzgan Farah

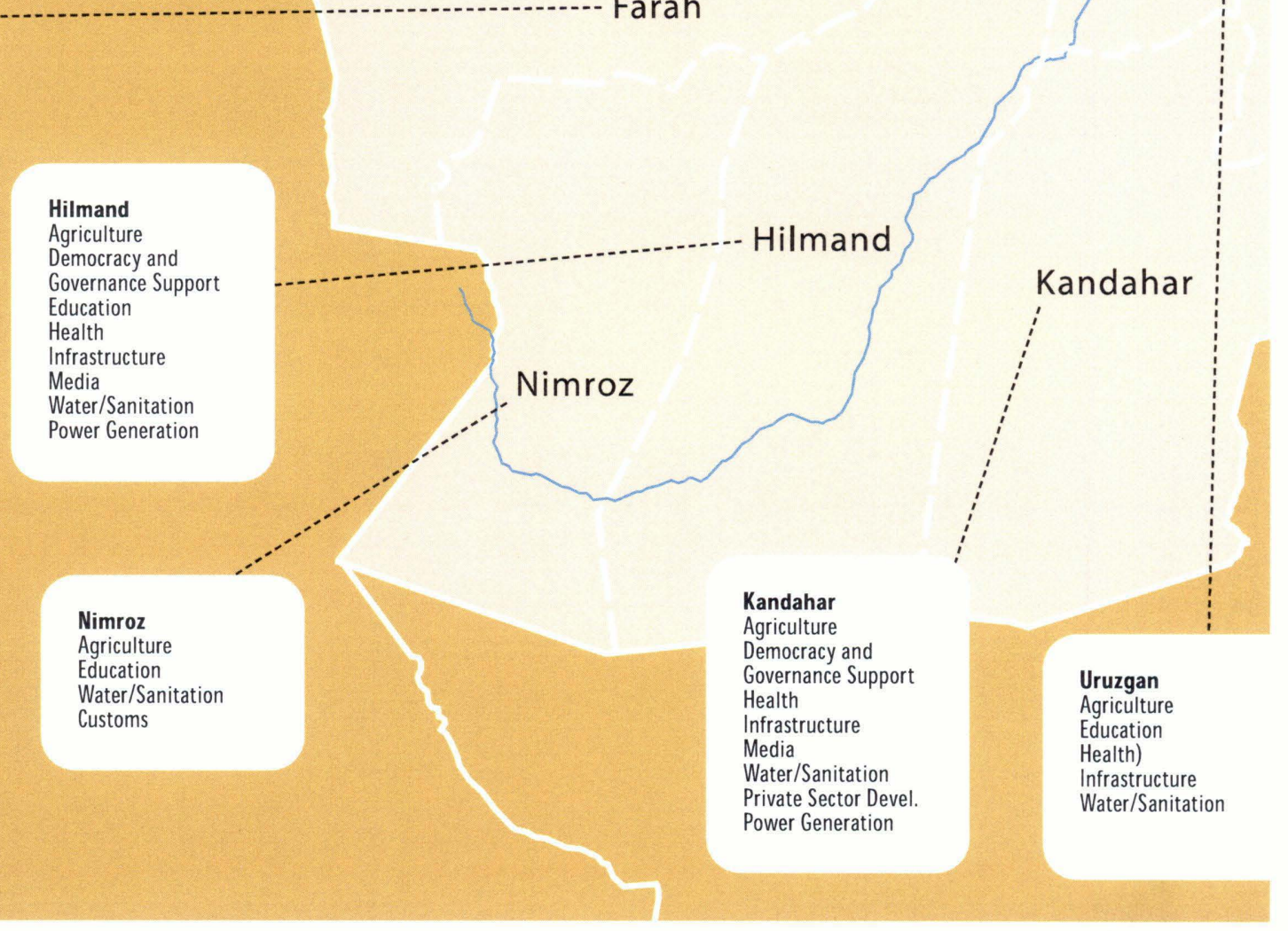


"Today, clean water is being provided throughout the country, hospitals and clinics have been rehabilitated, and millions of children have been vaccinated against measles and polio.

Three years ago, women were viciously oppressed and forbidden to work outside the home, and even denied what little medical treatment was available. Today, women are going to school, and their rights are protected in Afghanistan's constitution."

1 President George W. Bush June 15, 2004

"The Afghan people want to live in peace, they want to live in freedom, they want to live in a democracy. They are demonstrating that in so many ways, by the rebuilding that is taking place in Kabul, by their willingness to participate in the process of electing a new government... You see it in the mere fact that some three million refugees have returned to their homes, voting with their feet for the future of their country."

Secretary of State Colin Powell March 31, 2004
"Afghans have already made huge advances from life under a cruel, medieval theocracy that barred girls from school, kept women from public life and amputated limbs as a punishment. Today Afghanistan is a land of bustling markets, schools filled with eager students and people enjoying a new birth of freedom. We can be proud of what we have helped this unique and courageous people to achieve and we will remain at their side as they work to build a better future for their children."

USAID Administrator Andrew S. Natsios 


\section{Ten Major Achievements}

I Democratic elections: 7 million voted for president in 2004, and for parliament and provincial councils in 2005.

2 Roads link the country: Kabul-Kandahar road built; Kandahar-Herat road nearly complete; $800 \mathrm{~km}$ of local roads.

3 Agricultural output rises: Grain up 24\%; livestock and poultry income up $\$ 200$ million.

4 Fighters choose peace: 60,000 ex-combatants gave up weapons and joined civilian work force.

5 Domestic revenue up: $\$ 260$ million in 2005.

6 Healthcare expands: Reaches 7 million people.

7 Older students catch up: 170,000 make up lost years in accelerated learning program.

8 Construction expands: Thousands of homes and offices are built in cities and towns.

1. 5 million refugees return:

Largest return in history continues from Pakistan refugee campsiand/ran.

10 Education booms: 3.2 millioh boys and 1.8 million girls enrolled.

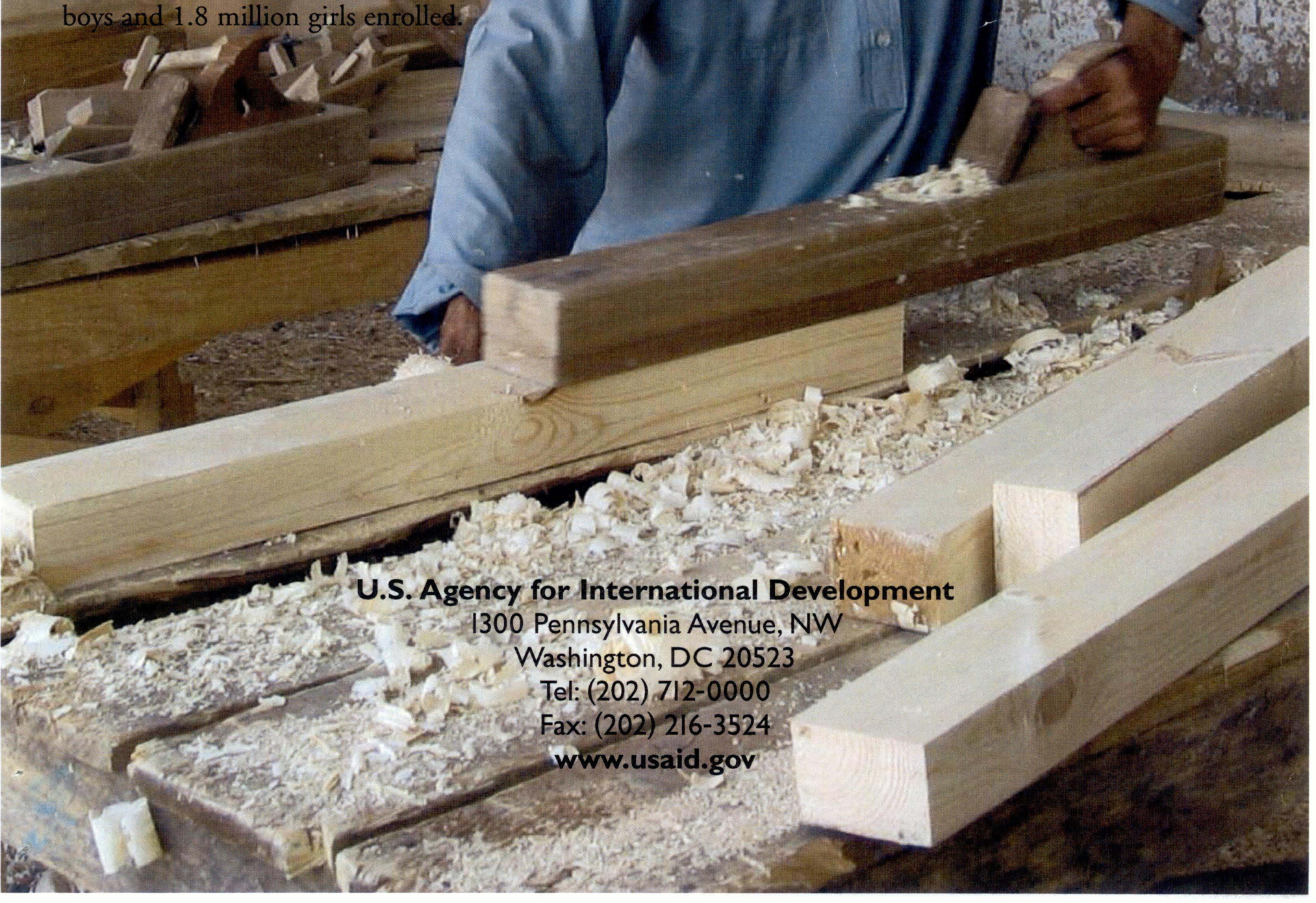


Afghanistan is reborn with international help

110 million Afghans registered to vote Despite the threat, most Afghans are registered to vote in the upcoming elections. More than $40 \%$ are women. Page 5

2 Five million children vaccinated Rehabilitated 72 clinics and hospitals. Page 10

3 School enrollment explodes Enrollment rises from 900,000 to 5 million, as girls attend classes for the first time in a decade. Page 7

4 Reconstruction accelerates More than $\$ 8$ billion in international aid pledged.

Kabul-Kandahar road completed, linking the country's two biggest cities. Page 12-15

$5 \quad 3.7$ million refugees return After years in Pakistani and Iranian camps, 100,000 Afghan refugees return each month, the largest voluntary return in modern history. Page 2

6 Private construction booming Markets, homes and mosques rise next to rubble from past conflict. For the first time in years, Kabul enjoys a building boom. page 13

7 New Afghan eurrency introduced The new Afghani, along with economic and financial reforms, is creating confidence as businesses invest and expand. Page 16

8 Agrieulture output nearly doubled In 2002, new seed varieties, fertilizer and restored irrigation systems helped farmers raise output $80 \%$. Page 17

9 Afghan National Army and National Police created Some 14,000 ANA troops and 25,000 police have been trained and deployed around country. Page 18

10 Regional militias disarming Thousands of fighters who fought the Soviets and the Taliban are giving up their weapons and getting training for civilian jobs. Page 19

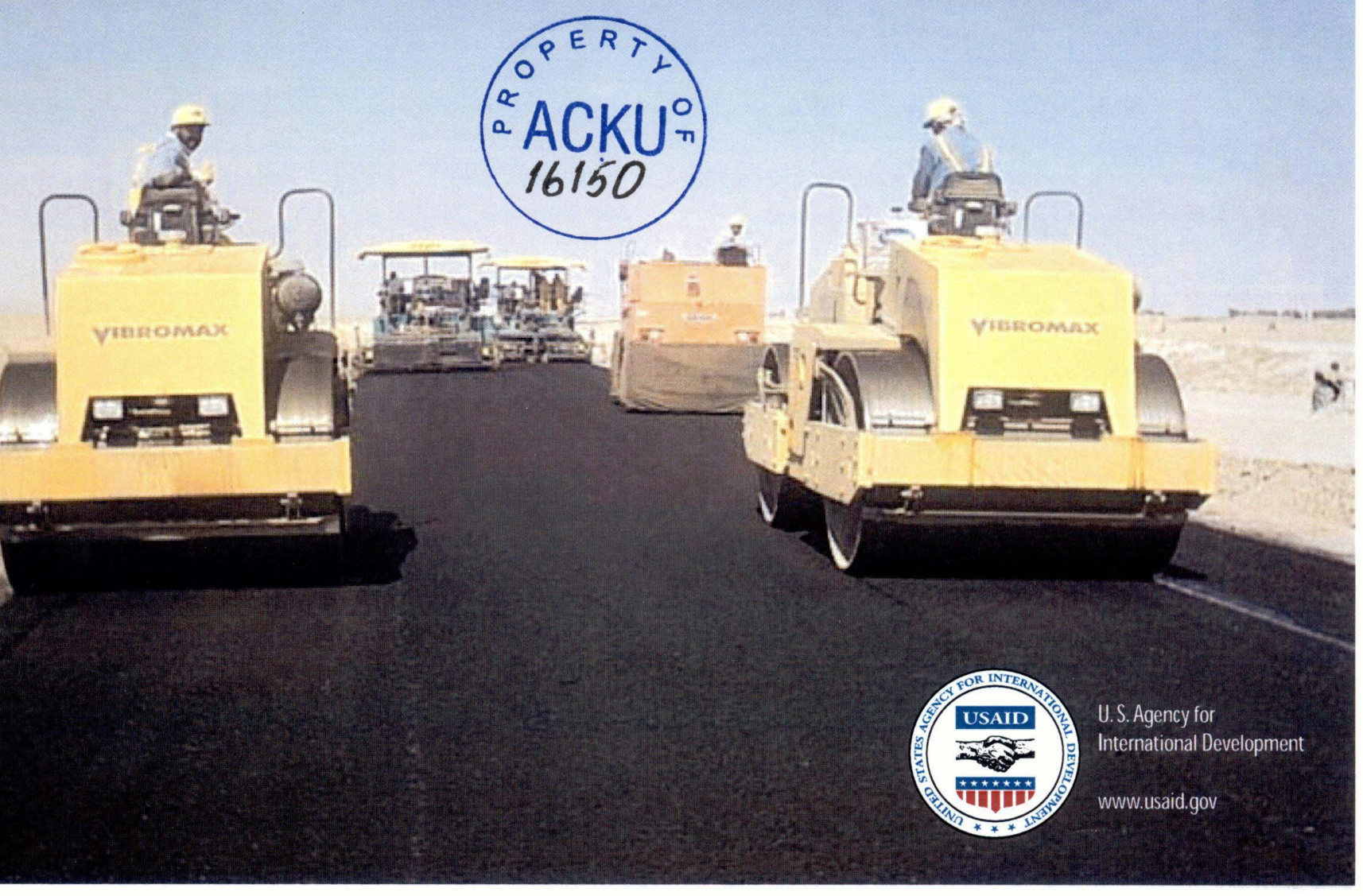

